\title{
Approaches to hepatitis $C$ treatment and cure using NS5A inhibitors
}

This article was published in the following Dove Press journal:

Infection and Drug Resistance

5 March 2014

Number of times this article has been viewed

\author{
James J Kohler ${ }^{1,2}$ \\ James H Nettles ${ }^{1,2}$ \\ Franck Amblard ${ }^{1,2}$ \\ Selwyn J Hurwitz ${ }^{1,2}$ \\ Leda Bassit ${ }^{1,2}$ \\ Richard A Stanton' \\ Maryam Ehteshami' \\ Raymond F Schinazi ${ }^{1,2}$
}

'Center for AIDS Research and Department of Pediatrics, Emory University School of Medicine, Atlanta, GA, USA; ${ }^{2}$ Atlanta Veterans Affairs Medical Center, Decatur, GA, USA

Correspondence: Raymond F Schinazi Laboratory of Biochemical Pharmacology, Department of Pediatrics, Emory University, Health Sciences Research Building, Room E-4 I8, 1760 Haygood Drive, Atlanta, GA 30322, USA

Tel + I 404727 I4I4

Fax +I 404727 I330

Email rschina@emory.edu
Abstract: Recent progress in the understanding of hepatitis $\mathrm{C}$ virus (HCV) biology and the availability of in vitro models to study its replication have facilitated the development of directacting antiviral agents (DAAs) that target specific steps in the viral replication cycle. Currently, there are three major classes of DAA in clinical development: NS3/4A protease inhibitors, NS5B polymerase inhibitors, and NS5A directed inhibitors. Several compounds thought to bind directly with NS5A are now in various clinical trial phases, including the most advanced, daclatasvir (BMS-790052), ledipasvir (GS-5885), and ABT-267. While many NS5A-targeted compounds demonstrate picomolar potency, the exact mechanism(s) of their action is still unclear. In the clinic, NS5A HCV inhibitors show promise as important components in DAA regimens and have multifunctionality. In addition to inhibiting viral replication, they may synergize with other DAAs, possibly by modulating different viral proteins, to help suppress the emergence of resistant viruses. Structure-based models have identified target interaction domains and spatial interactions that explain drug resistance for mutations at specific positions (eg, residues 93 and 31) within NS5A and potential binding partners. This review provides, insights into the unique complexity of NS5A as a central platform for multiple viral/host protein interactions, and possible mechanism(s) for the NS5A inhibitors currently undergoing clinical trials that target this nonstructural viral protein.

Keywords: HCV replication complex, direct acting antivirals (DAAs), clinical trials

\section{Introduction}

Hepatitis $\mathrm{C}$ virus (HCV) is a global health burden, with approximately 170 million people ( $3 \%$ of the world's population) estimated to be infected worldwide. ${ }^{1}$ More than three million people contract HCV each year, ${ }^{2}$ and while $15 \%-30 \%$ of all $\mathrm{HCV}$ infections clear spontaneously, ${ }^{3}$ the remaining 70\%-85\% (an estimated 120-130 million) of infections will develop into chronic hepatitis, which can lead to steatosis, cirrhosis, and hepatocellular carcinoma. ${ }^{4}$ Unfortunately, most are unaware of their infection - HCV-associated liver diseases may only manifest after decades in undiagnosed individuals - and can potentially transmit the virus to others, primarily through contaminated blood. ${ }^{5}$ In addition, HCV reinfection after treatment has been reported, making vaccine development desirable. ${ }^{6}$ Accordingly, the burden of HCVassociated disease is predicted to rise over the next 20 years. ${ }^{7}$ In fact, in the US, HCV has now superseded human immunodeficiency virus type 1 (HIV-1) as the leading cause of mortality due to an infectious agent. ${ }^{1}$

As a member of the Flaviviridae, the general replication cycle of HCV is similar to that of other viruses of this family and replicates entirely within the cytoplasm. ${ }^{8}$ 
Because it does not establish latency, HCV is curable, although the mechanism by which it mediates persistence remains unclear. Among all recognized positive-strand ribonucleic acid (RNA) viruses, $\mathrm{HCV}$ is unique in its ability to establish a chronic infection. ${ }^{9}$ The HCV genome consists of a $9.6 \mathrm{~kb}$, positive-sense, single-stranded, enveloped RNA, which encodes three structural proteins (core, E1, and E2), the ion channel protein $\mathrm{p} 7$, and six nonstructural (NS) proteins (NS2, NS3, NS4A, NS4B, NS5A, and NS5B). ${ }^{10}$ Each of these proteins has a role in $\mathrm{HCV}$ entry, infection, replication, or maturation and is therefore a potential drug target.

$\mathrm{HCV}$ is highly heterogeneous, which can be an obstacle to the development of a universal treatment and a preventative vaccine. According to the World Health Organization, six major HCV genotypes and several subtypes have been identified throughout the world. Subtypes 1a/b account for approximately $70 \%$ of all infections in the US, Europe, China and Japan, ${ }^{11}$ and the remainder are generally genotype 2, 3, and $4 .{ }^{12}$ The HCV genotype strongly predicts the response to the currently approved HCV treatments.

Over the last decade, the standard of care comprised a dual-therapy regimen containing peginterferon alpha (PEG-IFN), given once per week as a subcutaneous injection, and ribavirin (RBV), a guanosine (ribonucleic) analog given orally twice daily. Individuals with $\mathrm{HCV}$ genotype 1 or 4 infection are less likely $(40 \%-50 \%)$ to demonstrate a sustained viral response (SVR) with these treatments compared with individuals with genotype 2 or 3 disease (75\%-85\%). ${ }^{13,14}$ In 2011, the first NS3/4A HCV protease inhibitors (PIs), telaprevir and boceprevir, were approved. These direct-acting antiviral agents (DAAs) have now been licensed in several countries for use in combination with PEG-IFN and RBV, for the treatment of genotype 1 subjects. Unfortunately, many infected individuals, regardless of genotype, have been ineligible or unable to tolerate the standard of care regimen due to adverse effects and long treatment durations. Therefore, newer treatments with improved characteristics are needed to address the growing unmet medical needs.

HCV primarily infects liver parenchymal cells (hepatocytes). Because the liver is a highly specialized and complex organ, it is difficult to adequately model its biology in vitro. However, significant efforts have been directed at developing cell culture models to elucidate the viral replication in vitro. ${ }^{15,16}$ Specifically, the discovery of host cell receptor molecules that potentiate $\mathrm{HCV}$ infection has helped to overcome these obstacles, and the development of human hepatoma cell lines (eg, Huh-7 and Hep3B cells) has led to recent advances in the understanding of HCV structure and replication. ${ }^{10,15}$

There is now a broad pipeline of drugs in clinical development for treatment of HCV that relies on DAAs alone. DAAs block viral production by directly inhibiting one or more steps of the HCV replication cycle and are in various stages of clinical development. ${ }^{13,17-24}$ DAAs currently include firstgeneration, second-wave, and second-generation NS3/4A PIs, nucleoside inhibitors and nonnucleoside inhibitors of the NS5B RNA polymerase, and NS5A complex inhibitors. ${ }^{25-28}$ Highly potent once-a-day, DAA-only combinations are now in Phase II and III of clinical development. ${ }^{20}$ This review will focus on the unique complexity of NS5A as a drug target, with its putative protein interactions and possible mechanism(s) of action. We will summarize the most recent mechanistic research on drugs targeting NS5A and the ongoing clinical trials with these agents.

\section{Structure and function of NS5A}

NS5A is a 447 amino acid (aa), zinc-binding phosphoprotein comprised of three domains separated by two linker regions (Figure 1). ${ }^{29}$ Structurally, the amino-terminus of NS5A comprises the amphipathic $\alpha$-helix, which is responsible for anchoring to the endoplasmic reticulum (ER) and ER-derived membranes, including lipid droplets (LDs)..$^{30,31}$

In one study, the structure encoded in the first 31 aas of HCV genotype 1a domain I (D-I) was determined, by nuclear magnetic resonance spectrometry (NMR), to include an extended amphipathic helix (AH), which oscillates in plane with the cytosolic surfaces of the model membrane bilayers and which is thought to be conserved for all genotypes (Figure 1). ${ }^{32}$ The remaining subdomains were subsequently crystallized using different truncated sequences of genotype 1b (Figure 1). ${ }^{33,34}$ Both three-dimensional (3D) structures reveal a novel folded core between aa 36-100 designated as subdomain 1a (D1a), that coordinates a zinc atom via four cysteines, yet the two structures pack into two unique conformations of the homodimer. The remaining residues in D-I (aa 101-213), designated subdomain 1b (D1b), include a putative RNA-binding domain at the dimer interface of one of the structures. ${ }^{33}$ The structural predictions were recently confirmed by in vitro biochemical assays, where the D-I residues involved in dimerization and RNA binding were identified. ${ }^{35}$ Domains II (D-II) and III (D-III) of NS5A are intrinsically disordered and are therefore flexible. This may confer NS5A's promiscuous ability to interact with numerous proteins. ${ }^{36-40}$ Specifically, D-II is involved with binding to cyclophilin A and, therefore, has the potential to antagonize the innate 


\begin{tabular}{|c|c|c|c|c|c|c|c|c|c|c|c|c|}
\hline A 1 & 36 & & & & & 250 & D-II & 342 & & 356 & D-III & 447 \\
\hline$A H$ & i & $D 1 a$ & i & $D 1 b$ & LCS-I & & & & LCS-II & & & \\
\hline
\end{tabular}

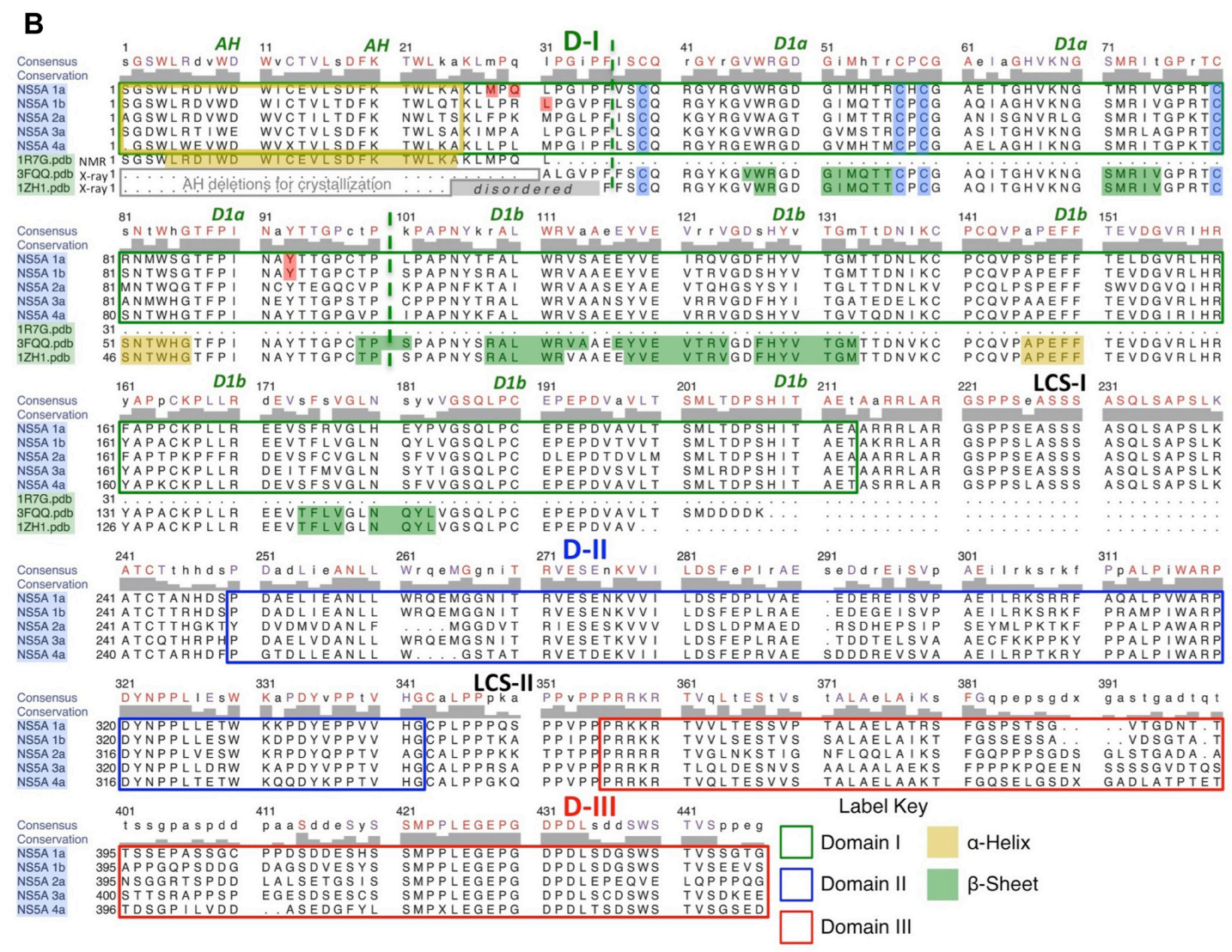

Figure I Domain organization schematic for the NS5A protein.

Notes: (A) D-I (aa I-2 I3), D-II (aa 250-342), and D-III (aa 356-447) are depicted with green, blue, and red boxes, respectively. Each domain is separated by an LCS (LCS-I and LCS-II). The $\mathrm{N}$-terminal AH is depicted with a yellow box. Dla and I ${ }^{33}$ are designated by dashed green lines. Domain numbering is from Tellinghuisen et al..29 (B) Rows (I-5) show the sequence alignments and domain outlining of the HCV NS5A genotypes Ia, Ib, 2a, 3a, and 4a. Conserved and consensus residues are in red and black on the top line. The critical $\mathrm{N}$-terminal, membrane binding, AH subdomain (aa I-25) of DI is outlined in gold. The critical conserved Cys residues that bind $\mathrm{Zn}^{++}$in subdomain Dla are shaded blue. The proposed RNA-binding subdomain is DIb. Positions 28, 30, 3I, and 93 (shaded red) are clinically observed mutations to NS5a-directed inhibitor treatment, which are also associated with high cell-based resistance. Rows (6-8) show the sequence of experimental 3D structures R7G.pdb (by NMR, aa I-31), 3FQQ.pdb (by X-ray diffraction, aa $3 \mathrm{I}-207$ ), and IZHI.pdb (by X-ray diffraction, aa 25-198) based on genotypes Ia, Ib, and Ib, respectively.

Abbreviations: 3D, three-dimensional; aa, amino acid; AH, amphipathic helix; Cys, cysteine; HCV, hepatitis C virus; LCS, low complexity sequence; NMR, nuclear magnetic resonance; NS5A, nonstructural protein 5A; Pdb, protein data bank; RNA, ribonucleic acid; D, domain.

immune response to $\mathrm{HCV}^{41} \mathrm{D}-\mathrm{III}$ seems to be important for the assembly of infectious viral particles. ${ }^{42,43}$

NS5A exists in two forms (designated p56 and p58), based on electrophoretic mobility. ${ }^{44}$ The $\mathrm{p} 56$ form is primarily unphosphorylated or is basally phosphorylated by several kinases in different regions, ${ }^{45-47}$ and data suggests that $\mathrm{p} 58$ hyperphosphorylation is performed by casein kinase I isoform alpha. ${ }^{48}$ More recently, the essential host factor, lipid kinase phosphatidylinositol 4-kinase III alpha (PI4KIII $\alpha$ ) has been shown to bind NS5A and regulate its phosphorylation state. ${ }^{49}$ Surprisingly, the upregulation of PI4KIII $\alpha$ has been shown to result in lower levels of the hyperphosphorylated $\mathrm{p} 58 .{ }^{49}$ While the exact role of NS5A phosphorylation in regulating
HCV RNA replication is not completely understood, it may contribute to a switch between viral RNA replication versus RNA translation and/or packaging. ${ }^{50}$ Recent studies suggest that NS5A hyperphosphorylation appears to play different roles between in vitro and in vivo systems, and the degree and requirements for hyperphosphorylation may vary between different $\mathrm{HCV}$ genotypes and isolates. ${ }^{51,52}$

While NS5A is essential to HCV genome replication and is required for virion morphogenesis, its specific role in these processes has yet to be determined. What is certain is that $\mathrm{HCV}$, like virtually all plus-strand RNA viruses, has the hallmark feature of forming a membrane-associated replication complex composed of virus proteins, replicating RNA and 
altered cellular membranes. ${ }^{53,54}$ All the HCV NS proteins, including NS5A, interact with host cell membranes, either directly as membrane-binding proteins, or in the case of NS3, via interaction with the membrane-anchoring protein NS4A. ${ }^{16}$ The interaction of these viral proteins with the membrane forms tight structures that accumulate as a "membranous web" to house the viral replication complexes..$^{53}$

Even though NS5A has no known enzymatic activity, its interaction with the membranous web is critical for viral replication, and modification/deletion of specific residues of the membrane-binding AH domain impairs both ER localization and RNA replication. ${ }^{30,32,55}$ NS5A interacts with a myriad of cellular and viral factors, including viral RNA, which likely enables it to perform multiple roles within the virus replication cycle. For example, NS5A is a novel structural class of RNA-binding protein with the ability to bind to HCV RNA..$^{56-58}$ NS5A also colocalizes with other HCV-encoded and host proteins, which may facilitate virus particle production ${ }^{59}$ and mediate replication complex movement via an association with microtubules and actin filaments. ${ }^{60,61} \mathrm{~A}$ theoretical model of the membrane-bound NS5A D-I structure, with viral RNA as a platform for the assembly of replication complexes, is presented in Figure 2.

In addition to forming viral protein complexes within the membranous web, evidence suggests that NS5A interacts with diverse host proteins. For example, NS5A has attracted considerable interest because of its potential role in modulating the response to interferon (IFN)- $\alpha$ therapy ${ }^{62}$ although this remains controversial. NS5A also alters intracellular events (eg, calcium levels), which leads to oxidative stress and the activation of the nuclear factor kappa-light-chain enhancer of activated $B$ cells (NF- $\kappa \beta$ ) and signal transducer and activator of transcription (STAT-3) transcription factors in the liver. ${ }^{63,64}$ As previously referenced, NS5A was found to directly interact with PI4KIII $\alpha$ and stimulate its kinase activity, which reduces 558 hyperphosphorylation. ${ }^{49}$ Importantly, this leads to the formation of a phosphatidylinositol-4 phosphate (PI4P)-enriched membranous environment, which may be critical for the HCV replication cycle as the inhibition of PI4KIII $\alpha$ abrogates HCV replication. ${ }^{65}$ Also, PI4P has been shown to rearrange during $\mathrm{HCV}$ infection and to colocalize with NS5A. ${ }^{66}$ Most recently, the cytoplasmic sorting factor tail-interacting protein of $47 \mathrm{kD}$ (TIP47) was found to have a crucial role in the HCV replication cycle and to bind NS5A directly at the conserved AH residue tryptophan (W) 9.6768 In short, while the specifics of the $\mathrm{HCV}$ replication cycle have yet to be fully understood, it

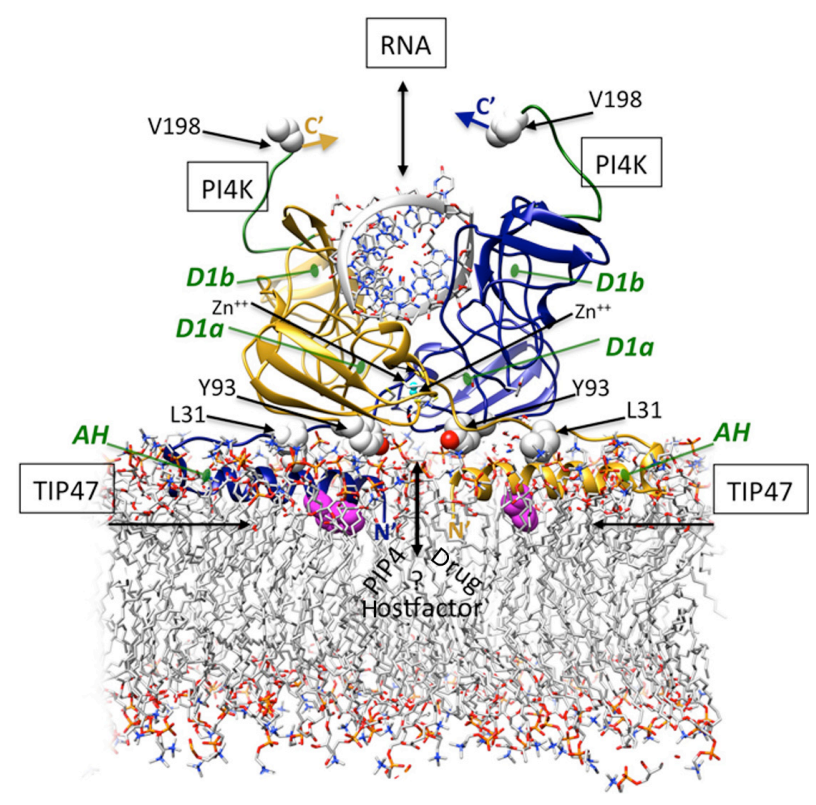

Figure 2 Structure-based theoretical model of membrane-bound NS5A DI homodimer binding RNA duplex.

Notes: The ribbon representations of the dimeric subunits are colored gold and blue. The $\mathrm{N}$-terminal $\mathrm{AHs}$ align in plane with the membrane and pack against residues $\mathrm{Y} 93$ and $\mathrm{L} 3 \mathrm{I}$ at the dimer interfaces. This $\mathrm{AH}$ conformation suggests potential binding site(s) for endogenous cofactors and drugs at the Y93/AH/dimer interfaces that may help explain the activity of NS5A direct inhibitors at different stages of replication and inhibition, and the effects on membranous web morphology. An atom of $\mathrm{Zn++}$ (cyan) binds at the Dla site at the core of each monomer, stabilizing a novel fold. RNA is shown binding at the DIb interface of this dimeric form. The recently identified regions for PI4K-binding at the C-terminal are colored green (182-198), and critical TIP47-binding residues near the AH N-termini are colored magenta. (The templates used PDB ID IZHI, PDB ID IR7G, POPC phospholipid bilayer). Reproduced with permission of James H Nettles. Copyright (c) 2013.

Abbreviations: $\mathrm{AH}$, amphipathic helix; DI, domain I subdomain I; NS5A, nonstructural protein 5A; PI4K, phosphatidylinositol 4-kinase; PIP4, phosphatidylinositol phosphate 4; pdb, protein data bank; RNA, ribonucleic acid; TIP47.

is likely that NS5A functions as a key modulator of this process.

\section{NS5A inhibitor mechanism(s) of action}

A recent clinical study of nine HCV-infected persons who were administered 10 or $100 \mathrm{mg}$ single doses of the NS5A inhibitor daclatasvir revealed a multiphasic decline in serum $\mathrm{HCV}^{69,70}$ An initial, rapid two- $\log _{10}$ drop in HCV RNA levels over the first 6 hours and a half-life $\left(t_{1 / 2}\right)$ of 48 minutes was observed, suggesting a direct inhibition of virus assembly or the secretion in serum. This was followed by a much slower phase of decline $\left(t_{1 / 2}=6-9\right.$ hours $)$, which was indicative of an effect on viral RNA synthesis. These clinical findings suggest that NS5A inhibitors have mechanism(s) that affect both viral genome replication and the assembly/release of infectious HCV particles in humans, related to those previously seen in cell-based studies.

In vitro experiments indicate that NS5A is a "promiscuous" protein, interacting with multiple host and virus 
components, most likely involved in the membranous web formation. ${ }^{53,71}$ For instance, NS5A has been shown to interact with core protein to enhance the formation of $\mathrm{HCV}$ particles $^{72-74}$ and with NS3, NS4A, and NS5B to modulate its phosphorylation, in addition to its role in binding RNA. ${ }^{33,56,57,75-77}$ However, it is not precisely clear which complex(es) are the target of NS5A-directed inhibitor drugs. Attempts at monitoring inhibition, in a cell-free system with only purified NS5A, have not been successful to date, suggesting that targeting the NS5A complex may require additional host and viral factors. On the other hand, the HCV replicon system has provided a rapid and efficient way to monitor the effects of NS5A inhibitors on HCV RNA production within the membranous web complex. It is noteworthy that the effect(s) of NS5A inhibitors on viral assembly and release cannot be studied directly using the replicon system, as replicon cells do not contain the envelope gene.

Recent mechanistic studies using immunofluorescence to track NS5A localization in replicon-containing cells following treatment with NS5A inhibitors have suggested that these drugs reduce viral RNA production in new, rather than preformed, replication complexes, which may correlate with the observed slow rate of viral load decay seen in clinical trials. ${ }^{78,79}$ These studies also demonstrated that NS5A inhibitors significantly shift the distribution of NS5A from the ER to LDs and that such redistribution is ablated in cells with drug-resistant mutations (eg, Y93H and L31V). ${ }^{78}$ Since NS5A has previously been shown to colocalize with core proteins on LDs, ${ }^{31,80}$ drug binding at the LD stage may interfere with viral assembly and particle release at the cell membrane, thus accounting for the fast decay (as part of the multiphasic decline) seen in the clinic.

Additional mechanisms for the biphasic clinical response to NS5A-targeted inhibitors may include functional complexes with essential host factors, such as PI4KIII $\alpha$ or TIP47. PI4KIII $\alpha$ creates a PI4P-rich membranous environment supporting HCV replication as well as modulating NS5A phosphorylation. ${ }^{49,81}$ TIP47 is an LD-binding host protein that has previously been shown to regulate RNA replication via direct interaction with HCV NS5A and to have a key role in the viral assembly/release of the related dengue flavivirus. ${ }^{82,83}$

While we have described at least two distinct possible modes of action for the drug response observed in infected persons, these modes of action are not likely to be exclusive. If NS5A inhibitors only affect the formation of new viral replication complexes, this mode of action would be limited to a relatively narrow time period in the $\mathrm{HCV}$ replication cycle; however, if NS5A inhibitors additionally affect the virus assembly complex, preventing the maturation of viral particles and the spread of infection, these mechanisms would occur at two different stages of the replication cycle and could account for the observed multiphasic kinetics. ${ }^{67,68}$

Both mechanisms suggest that the ideal NS5A inhibitors should be administered at doses that maintain steady-state trough concentrations $\left(\mathrm{C}_{\text {trough }}\right)$ that will maintain an SVR at week 12 (SVR12). Because it is assumed that only the unbound fraction of drug is free to diffuse into hepatocytes, many studies have reported maintenance of $\mathrm{C}_{\text {trough }}>$ the in vitro determined $90 \%$ effective concentration $\left(\mathrm{EC}_{90}\right)$ against the targeted strain of $\mathrm{HCV}$, corrected for binding to plasma proteins (protein-corrected potency), as a biomarker of therapeutic efficacy (Table 1). Once-a-day antiviral regimens generally demonstrate a greater degree of compliance. Oncea-day formulations are more easily achieved using drugs that have a long plasma $t_{1 / 2}$; eg, ledipasvir $\left(t_{1 / 2}=49.7\right.$ hours $)$, ABT-267 ( $t_{1 / 2}=28.1$ hours), and daclatasvir ( $t_{1 / 2}=12.8$ hours). However, given the high potency of NS5A inhibitors, drugs with short $t_{1 / 2}$ may also be considered as once-a-day regimens, provided a sufficiently high dose could be administered to maintain an effective steady-state trough without producing systemic toxicity. The pharmacokinetics of NS5A inhibitors in clinical development are summarized in Table 1.

\section{Chemical space of NS5A-directed inhibitors}

Daclatasvir was discovered using HCV replicon systems for high throughput screening (HTS), which identified a low micromolar hit that selected mutations in the NS5A coding region. ${ }^{84}$ Further screening of structurally similar compounds identified a low nanomolar lead that selected the same mutations ${ }^{84}$ Investigation of the mechanism of the lead's increased potency revealed a homodimeric metabolite to be the active component. ${ }^{85}$ Further medicinal chemistry optimization of the symmetric, dimeric scaffolds resulted in the picomolar-active structure of BMS-790052, also known as daclatasvir. ${ }^{85,86} \mathrm{~A}$ recent review mapped the chemical space of over 50 compounds from the patent literature. They were found to center around daclatasvir's chemical structure. ${ }^{27}$ This large set of compounds can be grouped into two general chemotype classes (summarized in Figure 3). The class 1 compounds are dimers presenting a chemical motif of two peptidic caps joined by conjugated aromatic core linkers and include the known clinical compounds daclatasvir (BMS-790052), GSK-2336805, and ledipasvir (65-5885), with the structures shown in Figure 3. The most 
Table I Pharmacokinetic parameters of NS5A inhibitors

\begin{tabular}{|c|c|c|c|c|c|c|c|c|}
\hline $\begin{array}{l}\text { NS5A } \\
\text { inhibitor }\end{array}$ & $\begin{array}{l}\text { Dose } \\
(\mathrm{mg})\end{array}$ & $\begin{array}{l}C_{\max } \\
(\mathrm{ng} / \mathrm{mL})\end{array}$ & $\begin{array}{l}T_{\max } \\
(\mathrm{hr})\end{array}$ & $\begin{array}{l}\text { AUC per dose } \\
(\mathrm{ng} \cdot \mathrm{hr} / \mathrm{mL})\end{array}$ & $t_{1 / 2}(h r)$ & $\begin{array}{l}C_{\text {trough ss }} \\
\text { (ng/mL) }\end{array}$ & $\begin{array}{l}\mathrm{PC} \mathrm{EC}_{90} \\
(\mathrm{ng} / \mathrm{mL})\end{array}$ & Refs \\
\hline ABT-267 ${ }^{\dagger}$ & $25 \mathrm{QD}$ & $56.2(38)$ & $4.6(16)$ & $529(36)$ & $28.1(22)$ & $31 . I^{*}$ & NA & $|24| 3 \mid$, \\
\hline $\mathrm{ACH}-3 \mathrm{IO}$ & 300 QD & $876.4(28)$ & $6.9(18)$ & $9,904.5(31)$ & IIII.6 (24) & 300 & NA & 125 \\
\hline \multirow[t]{2}{*}{ AZD-7295 } & 90 tid & 97.9 & $1.0-1.5$ & 294 & $4.4^{* *}$ & 29.5 & NA & 114,133 \\
\hline & 350 bid & 304.4 & $1.0-1.5$ & 1031 & $5.2^{* *}$ & 145.5 & & \\
\hline BMS-790052 & $60 \mathrm{QD}$ & $\mathrm{I}, 726(2 \mathrm{I})$ & $I(I-2)$ & $15,120(35)$ & $12.8(9.6)$ & $254.6(42)$ & Gen Ia, Ib: 0.28 & $99,126,134$ \\
\hline GS-5816 & I50 QD & $669(48.1)$ & $2-3$ & $4,890(45.4)$ & $15.2(12-15)$ & $63.4(42.8)$ & $\mathrm{N} / \mathrm{A}$ & 118 \\
\hline GS-5885 & 90 QD & $247.7(45.4)$ & $4-6$ & I,592.4 (59.5) & $49.7(54.3)$ & $115.9(42.6)$ & Gen I: 0.91 & 104,127 \\
\hline GSK-2336805 & 75 QD & NA & NA & $5,500(90)$ & $7-10$ & $128 *$ & NA & 116,132 \\
\hline \multirow[t]{2}{*}{ IDX-7I9 } & $50 \mathrm{QD}$ & $32.4(25)$ & $4(2-4)$ & $387(30)$ & $23(17)$ & $8.2(34)$ & Gen Ia/lb: $2.3 / I .7$ & 128,129 \\
\hline & 100 QD & $65.3(5 \mathrm{I})$ & $3(2-4)$ & $728(4.7)$ & $20(16)$ & I5.6 (4I) & Gen $2 a / 3 a: 6.7 / 5.4$ & \\
\hline PPI-668 & 320 QD & $1,500-5,000$ & 2 & NA & $6 * *$ & 311 & NA & 117 \\
\hline MK-8742 & NA & NA & & NA & NA & NA & NA & 130 \\
\hline
\end{tabular}

Notes: BMS-790052 = daclatasvir; GS-5885 = ledipasvir; IDX719 = samatasvir. The $C_{\text {max }}, C_{\text {trough ss }}$, and terminal $t_{1 / 2}$ were reported with \%CV or ranges (in parentheses), when available. Clinical doses may not be finalized; some dosages displayed were inferred from early conference presentation or press release. The PC EC ${ }_{90}$ were calculated using the replicon $\mathrm{EC}_{90}$, molecular weight, and/or serum protein binding. ${ }^{*}$ The $\mathrm{C}_{\text {trough }}$ was calculated by extrapolation using $\mathrm{C}_{\max }$ and $t_{1 / 2} * *{ }^{*} T_{1} t_{1 / 2}$ was estimated using the $\mathrm{C}_{\max }$, $\mathrm{C}_{\text {trough }}$, and dose interval $(\tau)$. ${ }^{\dagger}$ Coadministration of ABT-267 with ritonavir increased the mean $C_{\max }$ and AUC by $68 \%$ and $62 \%$, respectively, and by $88 \%$ and $56 \%$, respectively, when administered with food compared with administration under fasting conditions. 期e dose adjustments of BMS-790052 of $30 \mathrm{mg}$ QD with atazanavir (300 mg QD) plus ritonavir (100 mg QD), and of $90 \mathrm{mg}$ QD with efavirenz (600 mg QD) is expected to generate a daclatasvir exposure similar to that for $60 \mathrm{mg}$ of daclatasvir administered alone. - GSK-2336805 demonstrated a two- to fourfold greater $\mathrm{C}_{\max }$ and $\mathrm{AUC}$ in chronic HCV-infected than in healthy persons.

Abbreviations: $A U C$, area under the curve; bid, twice per day; $C_{\max }$, steady state maximal concentration; $C_{\text {trough ss, }}$, mean steady state trough concentrations; $C V$, coefficient of variation; $\mathrm{EC}_{90}, 90 \%$ effective concentration; HCV, hepatitis $\mathrm{C}$ virus; N/A, not available; NS5A, nonstructural protein 5A; PC EC 90 , protein corrected potency; QD, once per day, $t_{1 / 2}$, half-life; $T_{\text {max }}$, time to maximum concentration; tid, three times per day.

common cap is the proline-valine-carbamate motif seen in these three, while the linkers can vary widely. ${ }^{27}$ The class 2 compounds are distinct from class 1 and include monomers with very different chemical scaffolds. In general, the class 2 compounds are less active than Class 1 in replicon assays with nanomolar, rather than picomolar, median $50 \%$ effective concentration $\left(\mathrm{EC}_{50}\right)$ values. "Compound 4," with an $\mathrm{EC}_{50}$ of $160 \mathrm{nM}$, was the most potent, in vitro, of a series

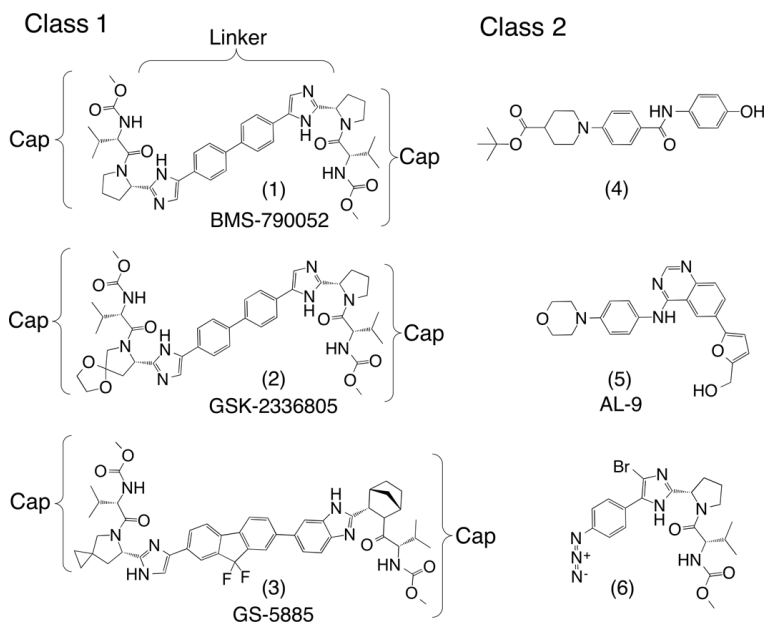

Figure 3 Representatives of the two general classes of NS5A-directed compounds found in the patent literature.

Notes: The dimeric class I compounds (I) (daclatasvir), (2), and (3) (ledipasvir) are the only three currently under clinical evaluation for which structures have been released. The class 2 compounds are diverse chemotypes and include monomers that do not fit class I (4-6). built on a piperazine-aryl scaffold from Merck and $\mathrm{Co}$, Inc (Whitehouse Station, NJ, USA) ${ }^{87}$ Mutations selected by this compound localize on NS5A, near the homodimer interface of the crystal structure, suggesting that effecting dimerization may be part of its molecular mechanism. ${ }^{87}$ However, some other class 2 members clearly point to alternative mechanism(s) of action for NS5A-targeted compounds. For example, 4-anilino quinazoline (AL-9) from Arrow Therapeutics Limited (London, UK) was first thought to target NS5A, based on selected mutations that emerged in NS5A. ${ }^{88}$ However, AL-9 was recently shown to directly inhibit purified PI4KIII $\alpha$ and to reduce PI4P levels in the plasma membrane, which are known to regulate viral propagation. ${ }^{89,90}$

Systematic explorations of the structure-activity relationships (SARs) for compounds from both class 1 and class 2 were recently reported by our group, in collaboration with RFS Pharma, LLC (Tucker, GA, USA). ${ }^{91-93}$ Briefly, analog libraries of symmetric dimer compound 1, sharing a proline-valine-carbamate cap, were synthesized in three series (Figure 4). Series 1 included replacement of the two "A" phenyl rings with shorter, nonaromatic linkers, but these substitutions resulted in $>1,000$-fold drop in potency. However, the straight aromatic linkers could be extended by up to five rings and still retain picomolar potency. ${ }^{93}$ The addition of specific halogen substitution at ring " $\mathrm{B}$ " was able to rescue the potency of an inactive parent compound with bent linkers, which suggests a key role for conformational 

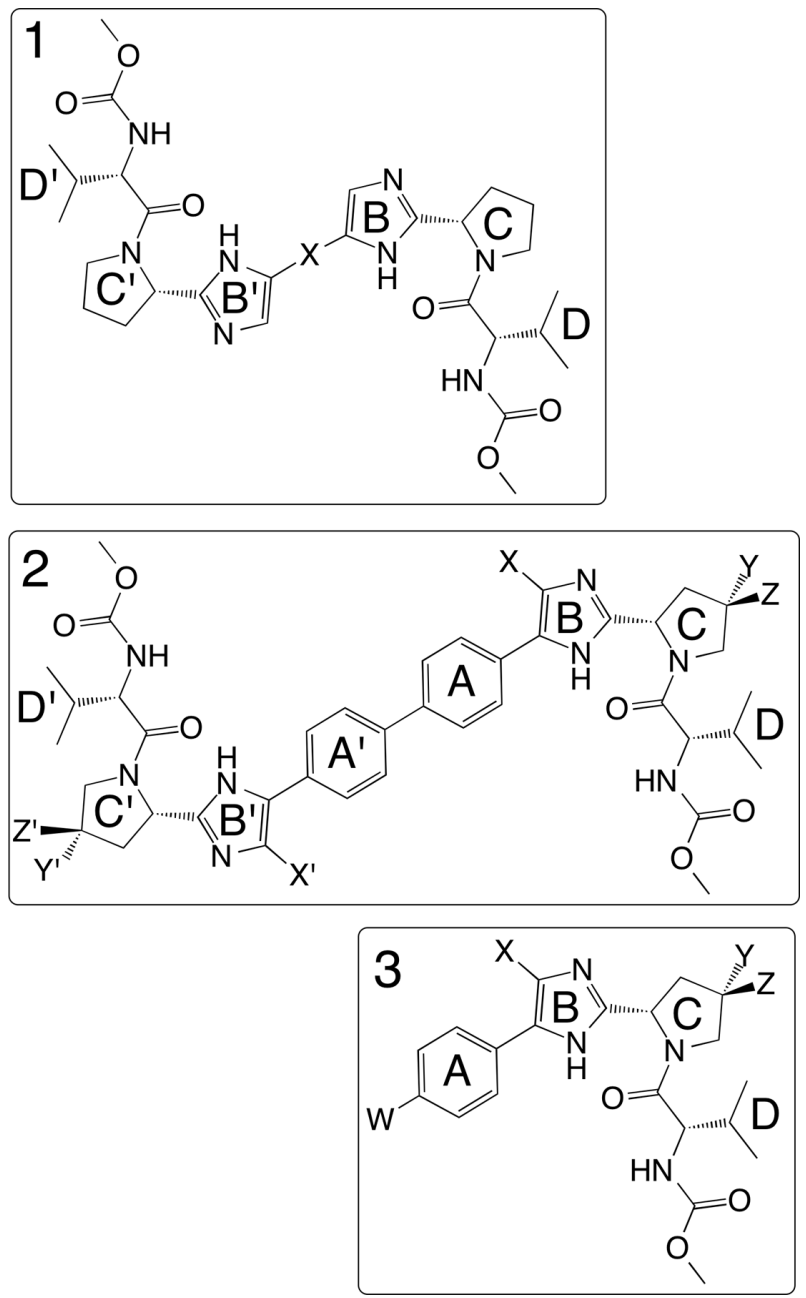

Figure 4 Three chemical series exploring systematic substitutions of a common compound I monomeric "cap" and relating specific features associated with activity across both class I (dimer) and class 2 (monomer) NS5a directed inhibitors.

stability related to potency. For series 2, symmetric halogen substitutions $(\mathrm{Cl}, \mathrm{Br}, \mathrm{I}$, or $\mathrm{F})$ at the $\mathrm{x}$ and $\mathrm{x}$ ' positions produced compounds with similar $\mathrm{EC}_{50}$ to the parent compound. Surprisingly, an aryl substitution at the imidazole region $\mathrm{B}$ maintained activity at $200 \mathrm{pM}$, and the oxaryl group improved potency to $26 \mathrm{pM}$, suggesting an open binding pocket in that region. In addition, an azido group substitution of the proline-like ring " $\mathrm{C}$ " at position y or $\mathrm{z}$ did not alter the activity $(\sim 20 \mathrm{pM})$, while larger 1,4 triazoles were only tolerated at position $\mathrm{z}$, suggesting stereochemical restraints of the binding pocket. ${ }^{92}$ Series 3 explored class 2 monomer activity. While the nonsubstituted scaffold was found to be completely inactive, a dual substitution with an azido group at position $\mathrm{w}$ and a bromo group at position x produced a highly active monomer, compound 6 , with picomolar inhibition of genotype $1 \mathrm{~b}$ replicons (Figure 3 ).${ }^{91}$ Resistance selection with both class 1 and 2 compounds in this series identified the emergence of NS5A mutations at positions 93 and 31, and modeling has also supported the potential of shared binding site(s) for highly active members of both classes (Schinazi, unpublished data, 2013).

Researchers at Pharmasset Inc (now Gilead Sciences, Foster City, CA, USA) used computational modeling to investigate the key pharmacophore responsible for the high activity of the class 1 dimers and theorized the importance of an intramolecular hydrogen bond between regions $\mathrm{B}$ and $\mathrm{C}$ to stabilize a conformation resembling a peptide "gamma-turn."94 Their development of a low picomolar active fluoroolefin-based mimetic supports that hypothesis and may provide a structural clue about the biological site of action. Although daclatasvir is both symmetric and dimeric by design, newer asymmetric and monomeric analogs have also been found to have high activity, suggesting that symmetry and high molecular weight dimers may not be a critical requirement for productive interactions with NS5A, in the next-generation compounds.

\section{Resistance and biological space of NS5A-directed inhibitors}

Overcoming acquired resistance is a major challenge for all antiviral targets, but for NS5A, acquired resistance defines the target. Daclatasvir, for example, was discovered using HCV replicon systems, which identified the rapid emergence of key resistance-bearing mutations at residues 31 and 93 in the NS5A coding region for genotypes $1 \mathrm{a}$ and $1 \mathrm{~b} .{ }^{84}$ Site-directed mutagenesis at those positions resulted in significant loss of drug activity and correlated with selection of the same mutations in clinical trials. ${ }^{86,95,96}$ The genotype $1 \mathrm{~b}$ mutations Y93H and L31V are striking examples of aa changes that individually increase resistance 24 - and 28 -fold, respectively, but which increase resistance 14,789-fold when combined ${ }^{97}$ (Table 2), suggesting a specific biological site for drug binding. The locations of these drug-resistant mutations within the AH-D1a linker and near the D1a/D1b interface are highlighted for genotype $1 \mathrm{~b}$ in Figure $1 \mathrm{~B}$.

The structure of aa 1-31 at the N-terminal of NS5A was elegantly solved by NMR in lipid bilayer models. It was found to form a flexible amphipathic $\alpha$-helix between residues 5-25 that inserted along the membrane surface with hydrophobic residues buried, polar residues exposed, and amphiphilic tryptophan residues aligned in plane (PDB ID 1R7G). ${ }^{32}$ The two 3D X-ray crystal structure solutions for subdomains D1a and D1b reveal very different dimer alignments (Figure 1). ${ }^{33,34}$ Because the deletion of $\mathrm{AH}$ was required for crystallization in each case, computational modeling has been employed to visualize the potential drug binding region at the $\mathrm{AH}-\mathrm{D} 1 \mathrm{a}$ 
Table 2 Resistance profile and fitness of daclatasvir, in genotype Ia and Ib replicon systems ${ }^{97}$

\begin{tabular}{|c|c|c|c|c|}
\hline Genotype & $\begin{array}{l}\text { Amino acid } \\
\text { substitutions }\end{array}$ & $\begin{array}{l}\text { Replication fitness (\%) } \\
\text { average } \pm \text { SD }\end{array}$ & $\begin{array}{l}\text { Potency } \mathrm{EC}_{50}(\mathrm{ng} / \mathrm{mL}) \\
\text { average } \pm \mathrm{SD}\end{array}$ & $\mathbf{F R}$ \\
\hline \multirow[t]{18}{*}{ Genotype Ia } & WT & 100 & $0.0044 \pm 0.0028$ & I \\
\hline & $\mathrm{M} 28 \mathrm{~A}$ & $27 \pm 25$ & $20.2 \pm 13.3$ & 4,591 \\
\hline & M28T & $31 \pm 23$ & $3.0 \pm 0.3$ & 682 \\
\hline & $\mathrm{M} 28 \mathrm{~V}$ & $16 \pm 11$ & $0.0055 \pm 0.0019$ & 1.3 \\
\hline & Q30E & $130 \pm 56$ & $110.9 \pm 66.0$ & 25,205 \\
\hline & $\mathrm{Q} 30 \mathrm{H}$ & $75 \pm 31$ & $6.5 \pm 1.4$ & $\mathrm{I}, 477$ \\
\hline & Q30R & $4 I \pm 16$ & $5.4 \pm 1.8$ & $\mathrm{I}, 227$ \\
\hline & Q30K & $19 \pm 9$ & $108 \pm 52$ & 24,545 \\
\hline & L3IM & $55 \pm 15$ & $1.5 \pm 0.5$ & $34 I$ \\
\hline & L3IV & $117 \pm 29$ & $14.9 \pm 4.4$ & 3,386 \\
\hline & $\mathrm{H} 58 \mathrm{D}$ & $92 \pm 9$ & $2.2 \pm 0.3$ & 500 \\
\hline & H58P & $266 \pm 261$ & $0.0053 \pm 0.0006$ & 1.2 \\
\hline & Y93C & $\mathrm{II} \pm 7$ & $8.2 \pm 3.0$ & $\mathrm{I}, 864$ \\
\hline & $\mathrm{Y93H}$ & $|8 \pm 1|$ & $23.9 \pm 7.0$ & 5,432 \\
\hline & Y93N & $13 \pm 8$ & $208.9 \pm 47.9$ & 47,477 \\
\hline & $M 28 V+Q 30 R$ & $147 \pm 55$ & $1.4 \pm 0.013$ & 350 \\
\hline & $\mathrm{Q} 30 \mathrm{H}+\mathrm{Y93H}$ & $20 \pm 6$ & $409.8 \pm 153.6$ & 93,136 \\
\hline & $\mathrm{Q} 30 \mathrm{R}+\mathrm{H} 58 \mathrm{D}$ & $60 \pm 12$ & I, $867 \pm 46$ & 424,318 \\
\hline \multirow[t]{10}{*}{ Genotype Ib } & WT & 100 & $0.0019 \pm 0.0007$ & I \\
\hline & L3IM & $99 \pm 23$ & $0.0062 \pm 0.0014$ & 3 \\
\hline & L3IV & $158 \pm 54$ & $0.053 \pm 0.015$ & 28 \\
\hline & Q54H & $83 \pm 18$ & $0.0024 \pm 0.0003$ & 1 \\
\hline & Q54N & $83 \pm 29$ & $0.0027 \pm 0.0006$ & I \\
\hline & $\mathrm{Y} 93 \mathrm{H}$ & $27 \pm 16$ & $0.046 \pm 0.018$ & 24 \\
\hline & $\mathrm{L} 3 \mathrm{IM}+\mathrm{Y} 93 \mathrm{H}$ & $70 \pm 68$ & $13.5 \pm 12.2$ & 7,105 \\
\hline & L3IV + Y93H & $50 \pm 38$ & $28.1 \pm 24.7$ & 14,789 \\
\hline & $\mathrm{Q} 54 \mathrm{H}+\mathrm{Y93H}$ & $22 \pm 7$ & $0.018 \pm 0.005$ & 9 \\
\hline & $\mathrm{L} 3 \mathrm{IV}+\mathrm{Q} 54 \mathrm{H}+\mathrm{Y} 93 \mathrm{H}$ & $189 \pm 25$ & $36.1 \pm 7.7$ & 19,000 \\
\hline
\end{tabular}

Note: Copyright @ 20II. John Wiley and Sons, Inc. This material is adapted with permission of John Wiley and Sons, Inc. from Fridell RA, Wang C, Sun JH, et al. Genotypic and phenotypic analysis of variants resistant to hepatitis $C$ virus nonstructural protein $5 \mathrm{~A}$ replication complex inhibitor BMS-790052 in humans: in vitro and in vivo correlations. Hepatology. 201 I;54(6): 1924-1935. ${ }^{97}$

Abbreviations: $\mathrm{EC}_{50}, 50 \%$ effective concentration; FR, fold resistance; SD, standard deviation.

interface. Cordek et al reported the use of a full-length NS5A AH-D1 homology model (combining the $\alpha$-helix from NMR with the dimer from PDB ID 3FQQ) to dock both class 1 and class 2 NS5A inhibitor compounds developed at GlaxoSmithKline, PLC (Brentford, UK). ${ }^{27}$ While residues 28, 30, and 31 were described to be in close proximity to Tyr 93 at the dimer interface of the model, the direct binding mode was reported as "elusive." ${ }^{27}$ More recently, a group from Bristol-Myers Squibb (New York, NY, USA) has proposed a symmetric binding mode at the dimer interface of their PDB ID 1ZH1-based structure; however, it does not easily explain the high activity of some class 2 compounds. ${ }^{98} \mathrm{~A}$ new structural review has also reported the potential for connecting AH from NMR to either of the X-ray crystal structures, but with ambiguity of the drug-binding detail. ${ }^{28}$ Our group has studied both dimer forms as platforms for building fulllength NS5A AH-D-I homology models and tested multiple possible AH-D1a linker conformations related to drug binding. We found the PDB ID 1ZH1 dimer template to provide better AH alignments, based on chemical genetics-derived distance constraints (J Nettles, unpublished data, 2013). Our analysis for docking NS5A inhibitors to both genotype 1a and $1 \mathrm{~b}$ models predicts the asymmetric drug binding of one cap between the pair of Tyr 93 residues at the $\mathrm{N}$-terminal $\mathrm{AH} / \mathrm{dimer} / \mathrm{membrane}$ interface, with a secondary cap interaction between 93 and 31 of the two monomers (Figure 5A). This binding mode can accommodate both class 1 and class 2 binding (J Nettles, unpublished data, 2013). These results further suggest a potential for conformational changes in the $\mathrm{AH}$ linker region that allows higher affinity asymmetric binding of the class 1 dimers to a membrane morphology associated with LDs (Figure 5B). The "open" 93/31 site allows the second cap to penetrate closer to the D1a core packing near residue 30 , consistent with the resistance data of Table 2 and the LD sequestering mechanism 


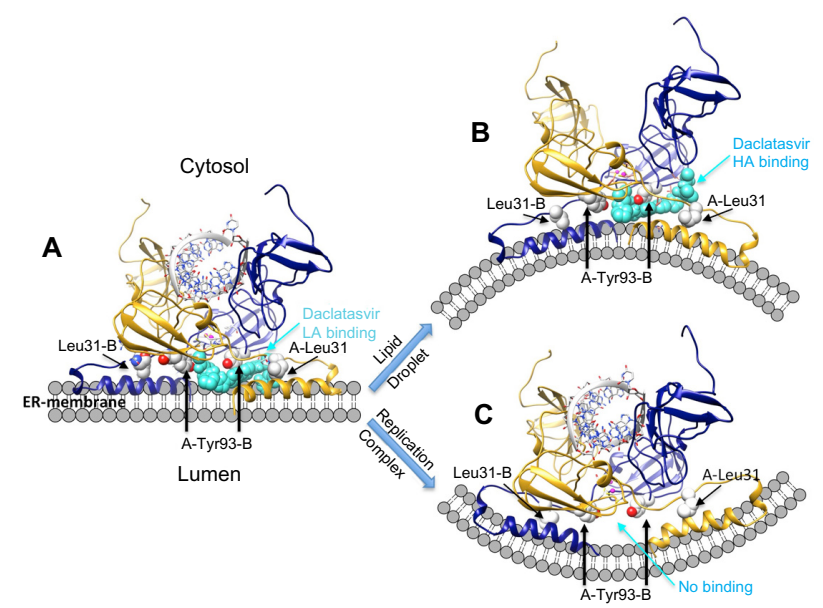

Figure 5 Theoretical models of daclatasvir (turquoise) binding to NS5A and potential AH mediated effect on membrane morphology.

Notes: The models suggest the drug (turquoise) binds simultaneously to two asymmetric sites at the NS5A A/B dimer/membrane interface (blue/gold). A core site between $\mathrm{Y} 93$ of each monomer binds one cap of the drug, while the second cap fits between residues 93 and 31 of the aligned subunits. (A) The aromatic linker provides favorable interactions and positions the caps simultaneously within the two LA sites formed by $\mathrm{AH}$ aligned in the membrane plane. (B) Conformational change of $\mathrm{AH}$ exposes an HA "open" drug site between 93 and 31 of the different subunits. Binding to this state may lock NS5A into a conformation conducive to lipid droplet formation and release to cytosol, and is thought to impair assembly of other viral oligomers. (C) NS5A binding with RNA, NS5B, and other proteins induces replication complex formation in a membranous web and significantly lowers the affinity for drug binding. Reproduced with permission of James H Nettles. Copyright (C) 2013.

Abbreviations: $\mathrm{AH}$, amphipathic helix; HA, higher affinity; LA, lower affinity; Leu, leucine; NS5A, nonstructural protein 5A; RNA, ribonucleic acid; Tyr, tyrosine.

suggested by Targett-Adams et al. ${ }^{78}$ Also consistent with the Targett-Adams results, the AH conformation associated with the replication complex does not support binding at either the $93 / 93$ or $93 / 31$ interfaces, due to a modified shape at the membrane interface (Figure 5C). Of note, these models of binding (Figure 5B) coincide with the BMS results reported by O'Boyle et al that a photoactive analog of daclatasvir was found to covalently bind a NS5A peptide spanning aa $21-30 .{ }^{98}$

\section{NS5A inhibitors in clinical trials}

According to http://www.clinicaltrials.gov, at least 13 potent NS5A DAAs have been evaluated in clinical trials (see Table 3). Among them, three drugs are currently in Phase III clinical trials, including daclatasvir, ledipasvir, and ABT-267; seven drugs are in Phase II, and three drugs are in Phase I. To date, only three structures have been released and are summarized in Figure 3.

\section{Drugs currently in Phase III clinical trials Daclatasvir/BMS-790052}

Daclatasvir/BMS-790052 (Bristol-Myers Squibb) is the firstin-class NS5A inhibitor of the HCV replication complex, which in humans, has demonstrated a rapid and robust HCV
RNA decline $\left(3.6 \log _{10}\right)$, with no signs of adverse effects. ${ }^{99}$ This compound blocks NS5A hyperphosphorylation and has the potential of shifting the subcellular localization of the viral protein. ${ }^{78,97}$ Daclatasvir has been shown to be highly effective against genotypes 1 and 2, and when in combination with IFN plus RBV, daclatasvir demonstrated a 100\% SVR at 12 weeks posttreatment in persons infected with genotype 4. Impressively, in a Phase II study using IFN-free regimens with or without $\mathrm{RBV}$, daclatasvir plus sofosbuvir (GS-7977) demonstrated a 100\% SVR at 4 weeks (SVR4) and a $100 \%$ SVR12 in genotype 1-infected subjects who were either treatment naïve or who had failed prior treatment with telaprevir or boceprevir plus PEG-IFN/RBV, and 91\% for genotypes 2- and 3-infected persons. ${ }^{100}$ Furthermore, when combined with NS3PI, this was the first compound to demonstrate the proof of concept that an IFN-free regimen could eradicate HCV. ${ }^{101}$ Based on the Phase II study results, which look promising, Phase III studies of the use of daclatasvir in combination with asunaprevir in genotype $1 \mathrm{~b}$ treatment-naïve individuals are currently ongoing, and studies of the combination with asunoprevir and BMS-791325 are planned to start shortly. ${ }^{102}$

\section{Ledipasvir/GS-5885}

Ledipasvir/GS-5885 (Gilead) demonstrated a high potency for HCV genotypes 1a (34 pM), $1 \mathrm{~b}$ (4 pM), 4a (110 pM), and $6 \mathrm{a}(110 \mathrm{pM})$ but lower activity against genotypes $2 \mathrm{a}(21 \mathrm{nM})$ and $3 \mathrm{a}(41 \mathrm{nM})$, with an excellent overall selectivity index (>800,000 in replicon cells). ${ }^{103}$ A Phase I clinical study ${ }^{104}$ of two doses showed a 2.3 and $3.3 \log _{10}$ HCV genotype 1 load reduction after 3 days of monotherapy (1 and $10 \mathrm{mg}$ QD [daily], respectively) but with quick emergence of resistance (residues 30 and 31 in genotype 1a and residue 93 in genotype 1b). During a first Phase II trial (ELECTRON), the combination of ledipasvir, sofosbuvir, and RBV led to $100 \%$ SVR for genotype 1 after 12 weeks, in treatmentnaïve individuals and prior nonresponders. Overall, the regimen was well tolerated: anemia (20\%), depression (8\%), and headache (4\%). ${ }^{105}$ A Phase II trial (LONESTAR) involving the combination of ledipasvir (QD) and sofosbuvir (QD) without RBV, for 12 weeks led to SVR4 in $19 / 19$ treatment-naïve and in 18/19 treatment-experienced genotype 1 subjects. ${ }^{106}$ In another study, the combination of ledipasvir (30 mg QD) with PEG-IFN (180 mg/week) plus RBV (1,000-1,200 $\mu \mathrm{g}$ /day) with or without GS-9451 (a NS3 PI, $200 \mathrm{mg}$ QD) led to a high SVR4 in treatmentnaïve ${ }^{107}$ and treatment-experienced ${ }^{108}$ subjects infected with $\mathrm{HCV}$ genotype 1 . The same combination led also to 
Table 3 NS5A agents in clinical development for chronic HCV infection

\begin{tabular}{|c|c|c|c|c|c|c|}
\hline $\begin{array}{l}\text { Drug name } \\
\text { (company) }\end{array}$ & Phase & $\begin{array}{l}\text { In vitro activity } \\
\mathrm{Ec}_{50}(\mathrm{pm})\end{array}$ & $\begin{array}{l}\text { Genotype } \\
\text { specificity }\end{array}$ & $\begin{array}{l}\text { Development } \\
\text { of resistance }\end{array}$ & $\begin{array}{l}\text { Drug combination } \\
\text { Phase I, Ila, Ilb, or III }\end{array}$ & $\begin{array}{l}\text { Adverse-effect } \\
\text { profile }\end{array}$ \\
\hline $\begin{array}{l}\text { Daclatasvir/ } \\
\text { BMS-790052 } \\
\text { (Bristol-Myers Squibb) }\end{array}$ & III & $9-50$ & $\mathrm{Ib}>2 \mathrm{a}>\mathrm{Ia}$ & $\begin{array}{l}\text { Low/intermediate } \\
\text { Y95H and L3IM }\end{array}$ & $\begin{array}{l}\text { Dual or triple with DAAs } \\
\text { SVR4/I2/24 (91\%-100\%) }\end{array}$ & $\begin{array}{l}\text { Headache, diarrhea, } \\
\text { nausea }\end{array}$ \\
\hline $\begin{array}{l}\text { Ledipasvir/GS-5885 } \\
\text { (Gilead) }\end{array}$ & III & $4-2.1 \times 10^{3}$ & $\begin{array}{l}I b>4 a, 6 a \\
>2 a, 3 a\end{array}$ & $\begin{array}{l}30 \text { and } 3 \mathrm{I} \text { in GTIa } \\
\text { and } 93 \text { in GTIb }\end{array}$ & $\begin{array}{l}\text { + Sofosbuvir (GS7977) } \pm \text { RBV } \\
\text { + PEG/RBV } \pm \text { GS-645I (NS3 PI) }\end{array}$ & $\begin{array}{l}\text { Anemia, depression, } \\
\text { headache }\end{array}$ \\
\hline ABT-267 (AbbVie) & III & $5-14$ & $1>2-6$ & Low/intermediate & $\begin{array}{l}\text { Dual or triple or quadruple } \\
\text { with DAAs/+RBV, } \\
\text { SVR8/I2 (87\%-98\%) }\end{array}$ & $\begin{array}{l}\text { Headache, nausea, } \\
\text { fatigue }\end{array}$ \\
\hline ACH-3I02 (Achillion) & II & $4-10$ & $\mathrm{I}-5$ & Low & $\begin{array}{l}\text { Single dose: HCV RNA levels } \\
\text { declined }>3.7 \log _{10} \text { in GTIa. } \\
\text { Dual with RBV initiated }\end{array}$ & $\begin{array}{l}\text { Phase I: no } \\
\text { significant adverse } \\
\text { effects }\end{array}$ \\
\hline IDX-7| 9 (Idenix) & II & $2-24$ & $\mathrm{I}-5$ & $\mathrm{Y93H}$ & $\begin{array}{l}\text { 3-day monotherapy: HCV levels } \\
\text { declined }>3 \log _{10} \text { for GTI-4. } \\
\text { Triple with DAAs initiated }\end{array}$ & $\begin{array}{l}\text { No significant } \\
\text { adverse effects }\end{array}$ \\
\hline MK-8742 (Merck) & II & $\begin{array}{l}\mathrm{Ia} / \mathrm{Ib}, 2 \mathrm{a}, 3 \mathrm{a}, \\
\text { and } 4 \mathrm{a}: 3-20 \\
2 \mathrm{~b}: 3 \times 10^{3}\end{array}$ & $1-4$ & Low & $\begin{array}{l}\text { Phase I - unavailable } \\
\text { Phase II: + RBV + MK-5I72 (PI) }\end{array}$ & Unavailable \\
\hline $\begin{array}{l}\text { AZD-7295/A-83I } \\
\text { (AstraZeneca/Arrow) }\end{array}$ & II & $\begin{array}{l}\text { lb: } 7 \times 10^{3} \\
\text { la: } 1.2 \times 10^{6}\end{array}$ & $\begin{array}{l}\text { No detectable } \\
\text { effect on Ia or } 3\end{array}$ & Unavailable & Unavailable & Unavailable \\
\hline $\begin{array}{l}\text { GSK2336805 } \\
\text { (GlaxoSmithKline) }\end{array}$ & II & I.8-44 & $\begin{array}{l}4 a, 5 a>1 b, 6 a b \\
>1 a>2 a, 3 a \\
6 c-g, 6 h-n\end{array}$ & Unavailable & $+V X-135 \pm R B V$ & Mild headache \\
\hline PPI-668 (Presidio) & Ila & $20-1.3 \times 10^{3}$ & $\mathrm{I}-7$ & Unavailable & $\begin{array}{l}+\mathrm{B} 1201335 \text { (faldaprevir) and } \\
\mathrm{B} 1207 \text { I } 27 \pm \mathrm{RBV}\end{array}$ & None \\
\hline GS-58I6 (Gilead) & II & $7-59$ & $1-6$ & Unavailable & + Sofosbuvir (GS-7977) & None \\
\hline EDP-239 (Novartis) & I & $4-34$ & $\mathrm{Ib}>\mathrm{Ia}$ & Unavailable & Currently undergoing Phase I & Unavailable \\
\hline ACH-2928 (Achillion) & I & $2-46$ & $1>2-6$ & Intermediate & 3-day monotherapy & $\begin{array}{l}\text { Anemia, fatigue } \\
\text { flu-like symptoms, } \\
\text { depression }\end{array}$ \\
\hline PPI-46I (Presidio) & I & Unavailable & $1-6$ & $28,30,31$, and 93 & NA & None \\
\hline
\end{tabular}

Notes: Bristol-Myers Squibb (New York, NY, USA); Gilead (Foster City, CA, USA); AbbVie (North Chicago, IL, USA); Achillion Pharmaceuticals (New Haven, CT, USA); Idenix Pharmaceuticals, Inc (Cambridge, MA, USA); Merck and Co, Inc (Whitehouse Station, NJ, USA); AstraZeneca (London, UK); Arrow Therapeutics Limited (London, UK); GlaxoSmithKline, PLC (Brentford, UK); Presidio Pharmaceuticals, Inc (San Francisco, CA, USA); Novartis Pharmaceuticals Corp (Basel, Switzerland).

Abbreviations: DAA, direct-acting antiviral agent; $\mathrm{EC}_{50}$, median effective concentration; GT, genotype(s); HCV; hepatitis $\mathrm{C}$ virus; NA, not available; NS5A, nonstructural protein 5A; PEG, peginterferon; PI, protease inhibitor; RBV, ribavirin; RNA, ribonucleic acid; SVR4/I2/24, sustained virologic response at week 4, I2, and 24 posttreatment; SVR8/I2, sustained virologic response at week 8 and 12 posttreatment.

high SVR12 rates in treatment-naïve, IL28B CC patients, which were comparable with the results of 24 weeks treatment with PEG-IFN plus RBV. ${ }^{109}$ The four-drug therapy (ledipasvir plus GS-9451 plus PEG-IFN plus RBV) was generally safe and well tolerated; however, treatment was discontinued due to a severe pancytopenia case. ${ }^{108,109}$ In October 2012, Gilead initiated a combination study called ION-1 in a treatment-naïve genotype $1 \mathrm{HCV}$-infected population, with fixed doses (QD) for 12 or 24 weeks of ledipasvir and sofosbuvir, with and without RBV, which led to SVR4 $>60 \%$, with no significant safety issues. ${ }^{110}$ A second follow-up study (ION-2) was initiated (January 2013) involving treatment of nonresponders infected with the HCV genotype 1, with fixed doses (QD) of ledipasvir and sofosbuvir, with RBV (12 weeks) or with/without
RBV (24 weeks). ${ }^{110} \mathrm{~A}$ third Phase III trial was initiated in May, 2013 (ION-3) comparing 8 weeks duration with 12 weeks duration, with fixed doses (QD) of ledipasvir and sofosbuvir with and without RBV, in 600 noncirrhotic, treatment-naïve HCV genotype 1 -infected subjects. ${ }^{106}$

\section{ABT-267}

A Phase III clinical trial involving the combination of three DAAs plus a protease booster and RBV is currently underway. In a Phase IIb clinical trial with a quintuple twice-a-day drug combination of ABT-267 (AbbVie, North Chicago, IL, USA) plus the PI ABT-450 plus ritonavir plus the nonnucleoside inhibitor ABT-333 plus RBV, a SVR12 of $98 \%$ and $93 \%$ was achieved in treatment-naïve persons and null responders infected with HCV genotype 1, respectively (Table 3). ${ }^{111}$ 


\section{Drugs currently in Phase II clinical trials ACH-3102}

ACH-3102 (Achillion Pharmaceuticals) is a potent secondgeneration NS5A inhibitor with a demonstrated high pharmacologic barrier to resistance and a low potential for the emergence of resistant variants in genotype 1 replicon systems. In a Phase Ia clinical trial, ACH-3102 demonstrated a rapid and robust HCV RNA decline (3.6-4.6 $\log _{10}$ range) in genotype 1-infected subjects. ${ }^{107} \mathrm{~A}$ Phase II clinical trial of ACH-3102 with RBV has been initiated (Table 3). ${ }^{100}$

\section{Samatasvir (IDX7|9)}

Samatasvir (Idenix Pharmaceuticals, Inc, Cambridge, MA, USA) has been shown to be highly potent against genotypes 1-4 in vitro; however, a low-resistance barrier to the $\mathrm{Y} 93 \mathrm{H}$ variant has been demonstrated with this NS5A inhibitor. Nevertheless, a Phase II clinical trial is planned with samatasvir plus two other DAAs (TMC647055, a nonnucleoside polymerase inhibitor; and simeprevir, a PI) from Janssen (Janssen Pharmaceuticals, Inc, Titusville, NJ, USA). ${ }^{112}$

\section{MK-8742}

MK-8742 (Merck) is a highly potent compound against genotype 1. It appears to function as a disruptor of the replication complex. In combination with MK-5172 (a PI), this candidate drug exhibited a high barrier to the development of escape mutants. ${ }^{113}$ Phase II clinical trials are underway.

\section{AZD-7295/A-83 I}

AZD-7295 (AstraZeneca, London, UK; Arrow Pharmaceutical, Inc) initially demonstrated promising potency against genotypes $1 \mathrm{~b}$ and $1 \mathrm{a}$ replicons $\left(\mathrm{EC}_{50}=7 \mathrm{nM}\right.$ and $1.24 \mu \mathrm{M}$, respectively). ${ }^{114}$ In 2008, a Phase II trial of AZD7295 was initiated. The status of this compound remains unknown.

\section{GSK2336805}

GSK2336805 (AstraZeneca/Arrow) is a highly potent NS5A inhibitor displaying a low $\mathrm{EC}_{50}$ for genotypes $1 \mathrm{a}(44 \mathrm{pM})$, $1 \mathrm{~b}(8 \mathrm{pM}), 4 \mathrm{a}(1.8 \mathrm{pM}), 5 \mathrm{a}(2.5 \mathrm{pM})$, and $6 \mathrm{ab}(9.1 \mathrm{pM})$ but less potency for genotypes $2 \mathrm{a}, 3 \mathrm{a}, 6 \mathrm{c}-\mathrm{g}$, and $6 \mathrm{~h}-\mathrm{n}$ isolates. A Phase I clinical trial showed that mild headache $(8 \%)$ was the only observed side effect after 7 and 14 days treatment with single $(10,30$, or $60 \mathrm{mg})$ and multiple $(10,30$, or $75 \mathrm{mg})$ oral doses in healthy adults. GSK2336805 resulted in a 0.93 to $3.9 \log _{10}$ load reduction after monotherapy $(1 \mathrm{mg}$ or $60 \mathrm{mg}$ QD, respectively) in treatment-naïve HCV genotype 1 subjects. ${ }^{115}$ Results of the Phase II, 12-week study involving a combination of GSK2336805 and VX-135 (uridine nucleotide prodrug, a NS5B polymerase inhibitor), with and without RBV, in treatment-naïve genotype 1 subjects have not been disclosed yet. ${ }^{116}$

\section{PPI-668}

The Presidio (Presidio Pharmaceuticals, Inc, San Francisco, CA, USA) second-generation NS5A inhibitor, PPI-668, showed potent pangenotypic activity, with an $\mathrm{EC}_{50}$ range between 0.02 and $1.3 \mathrm{nM}$ in replicon assays for HCV genotypes 1-7. During a Phase I, 3-day monotherapy study, PPI668 resulted in a 3.5-3.7 and $3.01 \log _{10}$ load reduction in genotypes 1 and 2-3 treatment- naïve persons, respectively. The treatment was well tolerated in both healthy volunteers (80-320 mg QD) and HCV-positive subjects (40-240 mg QD). ${ }^{17}$ A Phase IIa combination study with BI201335 (faldaprevir), a PI, and BI207127, a nonnucleoside HCV polymerase inhibitor, with or without ribavirin is planned.

\section{GS-5816}

GS-5816 (Gilead) is a potent second-generation NS5A inhibitor displaying low $\mathrm{EC}_{50}$ values $(7-59 \mathrm{pM})$ against genotypes 1-6. GS-5816 has also shown a high-resistance barrier and retains potency against common NS5A polymorphisms and resistance mutations $\left(\mathrm{EC}_{50}=130 \mathrm{pM}\right.$ against the L31M mutation and $121 \mathrm{pM}$ against the $\mathrm{Y} 93 \mathrm{C}$ mutation). In addition, GS-5816 was shown to remain active against mutations from other classes of HCV inhibitors and to show additive to moderately synergistic activities when combined with other anti-HCV agents (including sofosbuvir). ${ }^{118,119}$ A first-in-human, 7-day, Phase I study with healthy volunteers showed that GS-5816 was well tolerated at doses varying from 5 to $450 \mathrm{mg}$. Gilead is now moving on to a 12 -week, all oral Phase II study to evaluate GS-5816 (25 and $100 \mathrm{mg}$ ) in combination with sofosbuvir with and without RBV in treatment naïve persons with chronic genotype $1-6 \mathrm{HCV}$ infection. ${ }^{120}$

\section{Drugs currently in Phase I clinical trials ACH-2928}

ACH2928 (Achillion Pharmaceuticals, New Haven, CT, USA) is a highly potent NS5A inhibitor. In a 3-day, monotherapy Phase I clinical trial, this compound demonstrated an impressive and rapid reduction of HCV RNA levels $\left(3.7 \log _{10}\right)$ in persons infected with genotype $1 .{ }^{121}$

\section{EDP-239}

EDP-239 (Enanta Pharmaceuticals, Inc, Watertown, MA, USA; Novartis Pharmaceuticals Corp, Basel, Switzerland) 
is a potent NS5A-targeted molecule, which in vitro, has demonstrated picomolar activity against genotypes $1 \mathrm{~b}$ $\left(\mathrm{EC}_{50}=7 \mathrm{pM}\right)$ and $1 \mathrm{a}\left(\mathrm{EC}_{50}=31 \mathrm{pM}\right)$. The combination of EDP-239 with the cyclophilin inhibitor alisporivir resulted in a strong synergistic anti-HCV effect against genotypes $1-3 .^{27,122}$ Novartis has recently initiated Phase I clinical trials of EDP-239.

\section{PPI-46I}

PPI-461 (Presidio Pharmaceuticals, Inc), Presidio's firstgeneration NS5A inhibitor has shown potent in vitro activity for the HCV genotypes $1-6$ and up to a $3.6 \log _{10} \operatorname{load}$ reduction after 3 days of monotherapy ( 100 and $200 \mathrm{mg}$ oral doses) in HCV genotype 1-infected subjects. ${ }^{123}$ However, a rapid emergence of resistance was observed (at residues 28, 30, 31, and 93). Presidio's second-generation NS5A inhibitor, PPI-668, also has pangenotypic activity (described above).

\section{Conclusion}

Despite the current gaps in our understanding of NS5A, this NS protein has been implicated as an important modulator of critical viral functions, including viral RNA binding and replication, virus assembly, and regulation of the antiviral IFN response. Together, these roles present a unique platform for NS5A inhibitors, to be combined with more traditional target-based drug discovery. NS5A-directed compounds are considered to be the most potent anti-HCV molecules ever discovered. However, their Achilles heel is that they select drug-resistant mutants fast and to be effective, must be used with other potent DAA drugs, to prevent clinical resistance. Structure-based models have demonstrated the potential for identifying target domains and spatial interactions that rationalize the selection of resistance mutations at specific positions within NS5A and potential binding partners (eg, residues 93 and 31). Continued SAR studies will further elucidate the mechanism(s) of action of these small molecules and facilitate the discovery of new drugs with higher barrier to resistance.

NS5A-targeted therapies demonstrate a remarkable capacity to inhibit HCV RNA replication, with minimal in vivo toxicity. At least two molecules (daclatasvir and ledipasvir) are being clinically evaluated in IFN-free combination therapies. NS5A inhibitors appear to be emerging as important components of HCV DAA regimens with dual functionality. In addition to having picomolar potency, they can synergize with other DAA, targeting different viral proteins, to prevent and suppress the emergence of resistant viruses. If NS5A inhibitors can exercise their remarkable potency to rapidly drive down virus replication within the protection offered by other DAAs, then resistance to any one DAA component may be suppressed by other components in the combination regimens. Thanks to these advances, the future is looking promising for the millions of HCV-infected individuals. An IFN-free, oral, once-daily, pangenotypic drug combination of a nucleoside analog, such as sofosbuvir, with a next-generation pangenotypic NS5A drug, such as GS-5816, may play a pivotal role and could potentially cure millions of chronically infected HCV individuals and result in global HCV eradication in the near future.

\section{Acknowledgments}

This work was supported in part by National Institutes of Health grant 5P30-AI-50409 (Centers for AIDS Research) and by the Department of Veterans Affairs. The authors thank Judy Matthew for her careful editing of the manuscript.

\section{Disclosure}

The authors report no conflicts of interest in this work.

\section{References}

1. Lavanchy D. The global burden of hepatitis C. Liver Int. 2009; 29(Suppl 1):S74-S81.

2. Alter MJ. Epidemiology of hepatitis C virus infection. World $J$ Gastroenterol. 2007;13(17):2436-2441.

3. Lehmann M, Meyer MF, Monazahian M, Tillmann HL, Manns MP, Wedemeyer $\mathrm{H}$. High rate of spontaneous clearance of acute hepatitis C virus genotype 3 infection. J Med Virol. 2004;73(3):387-391.

4. Tong MJ, el-Farra NS, Reikes AR, Co RL. Clinical outcomes after transfusion-associated hepatitis C. N Engl J Med. 1995;332(22): $1463-1466$.

5. Alberti $\mathrm{A}$, Chemello L, Benvegnù L. Natural history of hepatitis $\mathrm{C}$. J Hepatol. 1999;31 Suppl 1:S17-S24.

6. Lambers FA, Prins M, Thomas X, et al; MOSAIC (MSM Observational Study of Acute Infection with hepatitis C) study group. Alarming incidence of hepatitis $\mathrm{C}$ virus re-infection after treatment of sexually acquired acute hepatitis $\mathrm{C}$ virus infection in HIV-infected MSM. AIDS. 2011;25(17):F21-F27.

7. Deuffic-Burban S, Poynard T, Sulkowski MS, Wong JB. Estimating the future health burden of chronic hepatitis $\mathrm{C}$ and human immunodeficiency virus infections in the United States. JViral Hepat. 2007;14(2): 107-115.

8. Lohmann V. Hepatitis C virus RNA replication. Curr Top Microbiol Immunol. 2013;369:167-198.

9. Moore PS, Chang Y. Why do viruses cause cancer? Highlights of the first century of human tumour virology. Nat Rev Cancer. 2010;10(12): 878-889.

10. Moradpour D, Penin F. Hepatitis C virus proteins: from structure to function. Curr Top Microbiol Immunol. 2013;369:113-142.

11. Kim AI, Saab S. Treatment of hepatitis C. Am J Med. 2005;118(8): 808-815.

12. Wartelle-Bladou C, Le Folgoc G, Bourlière M, Lecomte L. Hepatitis C therapy in non-genotype 1 patients: the near future. J Viral Hepat. 2012;19(8):525-536.

13. Alexopoulou A, Papatheodoridis GV. Current progress in the treatment of chronic hepatitis C. World J Gastroenterol. 2012;18(42): 6060-6069. 
14. Zein NN, Rakela J, Krawitt EL, Reddy KR, Tominaga T, Persing DH. Hepatitis $C$ virus genotypes in the United States: epidemiology, pathogenicity, and response to interferon therapy. Collaborative Study Group. Ann Intern Med. 1996;125(8):634-639.

15. Wilson GK, Stamataki Z. In vitro systems for the study of hepatitis $\mathrm{C}$ virus infection. Int J Hepatol. 2012;2012:292591.

16. Moradpour D, Penin F, Rice CM. Replication of hepatitis C virus. Nat Rev Microbiol. 2007;5(6):453-463.

17. Barreiro P, Vispo E, Poveda E, Fernández-Montero JV, Soriano V. Hepatitis $C$ therapy: highlights from the 2012 annual meeting of the European Association for the Study of the Liver. Clin Infect Dis. 2013; 56(4):560-566.

18. Assis DN, Lim JK. New pharmacotherapy for hepatitis C. Clin Pharmacol Ther. 2012;92(3):294-305.

19. Shah N, Pierce T, Kowdley KV. Review of direct-acting antiviral agents for the treatment of chronic hepatitis C. Expert Opin Investig Drugs. 2013;22(9):1107-1121.

20. Kiser JJ, Flexner C. Direct-acting antiviral agents for hepatitis C virus infection. Annu Rev Pharmacol Toxicol. 2013;53:427-449.

21. Jesudian AB, Gambarin-Gelwan M, Jacobson IM. Advances in the treatment of hepatitis C virus infection. Gastroenterol Hepatol (NY). 2012;8(2):91-101.

22. Yang PL, Gao M, Lin K, Liu Q, Villareal VA. Anti-HCV drugs in the pipeline. Curr Opin Virol. 2011;1(6):607-616.

23. De Clercq E. The race for interferon-free HCV therapies: a snapshot by the spring of 2012. Rev Med Virol. 2012;22(6):392-411.

24. Farnik H, Zeuzem S. New antiviral therapies in the management of HCV infection. Antivir Ther. 2012;17(5):771-783.

25. Hunt D, Pockros P. What are the promising new therapies in the field of chronic hepatitis $\mathrm{C}$ after the first-generation direct-acting antivirals? Curr Gastroenterol Rep. 2013;15(1):303.

26. Belda O, Targett-Adams P. Small molecule inhibitors of the hepatitis C virus-encoded NS5A protein. Virus Res. 2012;170(1-2): $1-14$.

27. Cordek DG, Bechtel JT, Maynard AT, Kazmierski WM, Cameron CE Targeting the NS5A protein of HCV: an emerging option. Drugs Future. 2011;36(9):691-711.

28. Bartenschlager R, Lohmann V, Penin F. The molecular and structural basis of advanced antiviral therapy for hepatitis $\mathrm{C}$ virus infection. Nat Rev Microbiol. 2013;11(7):482-496.

29. Tellinghuisen TL, Marcotrigiano J, Gorbalenya AE, Rice CM. The NS5A protein of hepatitis C virus is a zinc metalloprotein. J Biol Chem. 2004;279(47):48576-48587.

30. Brass V, Bieck E, Montserret R, et al. An amino-terminal amphipathic alpha-helix mediates membrane association of the hepatitis $\mathrm{C}$ virus nonstructural protein 5A. J Biol Chem. 2002;277(10):8130-8139.

31. Shi ST, Polyak SJ, Tu H, Taylor DR, Gretch DR, Lai MM. Hepatitis C virus NS5A colocalizes with the core protein on lipid droplets and interacts with apolipoproteins. Virology. 2002;292(2):198-210.

32. Penin F, Brass V, Appel N, et al. Structure and function of the membrane anchor domain of hepatitis $\mathrm{C}$ virus nonstructural protein $5 \mathrm{~A}$. J Biol Chem. 2004;279(39):40835-40843.

33. Tellinghuisen TL, Marcotrigiano J, Rice CM. Structure of the zincbinding domain of an essential component of the hepatitis $\mathrm{C}$ virus replicase. Nature. 2005;435(7040):374-379.

34. Love RA, Brodsky O, Hickey MJ, Wells PA, Cronin CN. Crystal structure of a novel dimeric form of NS5A domain I protein from hepatitis C virus. J Virol. 2009;83(9):4395-4403.

35. Lim PJ, Chatterji U, Cordek D, et al. Correlation between NS5A dimerization and hepatitis C virus replication. J Biol Chem. 2012; 287(36):30861-30873

36. Gupta G, Qin H, Song J. Intrinsically unstructured domain 3 of hepatitis C Virus NS5A forms a "fuzzy complex" with VAPB-MSP domain which carries ALS-causing mutations. PLoS One. 2012;7(6):e39261.

37. Hanoulle X, Badillo A, Verdegem D, Penin F, Lippens G. The domain 2 of the HCV NS5A protein is intrinsically unstructured. Protein Pept Lett. 2010;17(8):1012-1018.
38. Hughes M, Griffin S, Harris M. Domain III of NS5A contributes to both RNA replication and assembly of hepatitis $\mathrm{C}$ virus particles. J Gen Virol. 2009;90(Pt 6):1329-1334.

39. Liang Y, Ye H, Kang CB, Yoon HS. Domain 2 of nonstructural protein 5A (NS5A) of hepatitis C virus is natively unfolded. Biochemistry. 2007;46(41):11550-11558.

40. Ross-Thriepland D, Amako Y, Harris M. The C terminus of NS5A domain II is a key determinant of hepatitis $\mathrm{C}$ virus genome replication, but is not required for virion assembly and release. J Gen Virol. 2013;94(Pt 5):1009-1018.

41. Ansari IU, Striker R. Subtype specific differences in NS5A domain II reveals involvement of proline at position 310 in cyclosporine susceptibility of hepatitis C virus. Viruses. 2012;4(12):3303-3315.

42. Appel N, Zayas M, Miller S, et al. Essential role of domain III of nonstructural protein $5 \mathrm{~A}$ for hepatitis $\mathrm{C}$ virus infectious particle assembly. PLoS Pathog. 2008;4(3):e1000035.

43. Kim S, Welsch C, Yi M, Lemon SM. Regulation of the production of infectious genotype 1a hepatitis C virus by NS5A domain III. J Virol. 2011;85(13):6645-6656.

44. Kaneko T, Tanji Y, Satoh S, et al. Production of two phosphoproteins from the NS5A region of the hepatitis $\mathrm{C}$ viral genome. Biochem Biophys Res Commun. 1994;205(1):320-326.

45. Kim J, Lee D, Choe J. Hepatitis C virus NS5A protein is phosphorylated by casein kinase II. Biochem Biophys Res Commun. 1999;257(3):777-781.

46. Chen YC, Su WC, Huang JY, et al. Polo-like kinase 1 is involved in hepatitis $\mathrm{C}$ virus replication by hyperphosphorylating NS5A. J Virol. 2010;84(16):7983-7993.

47. Katze MG, Kwieciszewski B, Goodlett DR, et al. Ser(2194) is a highly conserved major phosphorylation site of the hepatitis $\mathrm{C}$ virus nonstructural protein NS5A. Virology. 2000;278(2):501-513.

48. Quintavalle M, Sambucini S, Di Pietro C, De Francesco R, Neddermann $\mathrm{P}$. The alpha isoform of protein kinase CKI is responsible for hepatitis C virus NS5A hyperphosphorylation. JVirol. 2006;80(22) 11305-11312.

49. Reiss S, Harak C, Romero-Brey I, et al. The lipid kinase phosphatidylinositol-4 kinase III alpha regulates the phosphorylation status of hepatitis C virus NS5A. PLoS Pathog. 2013;9(5):e1003359.

50. Huang Y, Staschke K, De Francesco R, Tan SL. Phosphorylation of hepatitis C virus NS5A nonstructural protein: a new paradigm for phosphorylation-dependent viral RNA replication? Virology. 2007; 364(1):1-9.

51. Lemay KL, Treadaway J, Angulo I, Tellinghuisen TL. A hepatitis C virus NS5A phosphorylation site that regulates RNA replication. J Virol. 2013;87(2):1255-1260.

52. Appel N, Pietschmann T, Bartenschlager R. Mutational analysis of hepatitis $\mathrm{C}$ virus nonstructural protein 5A: potential role of differential phosphorylation in RNA replication and identification of a genetically flexible domain. J Virol. 2005;79(5):3187-3194.

53. Egger D, Wölk B, Gosert R, et al. Expression of hepatitis C virus proteins induces distinct membrane alterations including a candidate viral replication complex. J Virol. 2002;76(12):5974-5984.

54. Gosert R, Egger D, Lohmann V, et al. Identification of the hepatitis C virus RNA replication complex in Huh-7 cells harboring subgenomic replicons. J Virol. 2003;77(9):5487-5492.

55. Elazar M, Cheong KH, Liu P, Greenberg HB, Rice CM, Glenn JS. Amphipathic helix-dependent localization of NS5A mediates hepatitis C virus RNA replication. J Virol. 2003;77(10):6055-6061.

56. Huang L, Hwang J, Sharma SD, et al. Hepatitis C virus nonstructural protein $5 \mathrm{~A}$ (NS5A) is an RNA-binding protein. $J$ Biolog Chem. 2005;280(43):36417-36428.

57. Hwang J, Huang L, Cordek DG, et al. Hepatitis C virus nonstructural protein 5A: biochemical characterization of a novel structural class of RNA-binding proteins. J Virol. 2010;84(24):12480-12491.

58. Targett-Adams P, Boulant S, McLauchlan J. Visualization of doublestranded RNA in cells supporting hepatitis $\mathrm{C}$ virus RNA replication. J Virol. 2008;82(5):2182-2195. 
59. Jirasko V, Montserret R, Lee JY, et al. Structural and functional studies of nonstructural protein 2 of the hepatitis $\mathrm{C}$ virus reveal its key role as organizer of virion assembly. PLoS Pathog. 2010;6(12):e1001233.

60. Lai CK, Jeng KS, Machida K, Lai MM. Association of hepatitis C virus replication complexes with microtubules and actin filaments is dependent on the interaction of NS3 and NS5A. J Virol. 2008;82(17): 8838-8848.

61. Lai CK, Jeng KS, Machida K, Cheng YS, Lai MM. Hepatitis C virus NS3/4A protein interacts with ATM, impairs DNA repair and enhances sensitivity to ionizing radiation. Virology. 2008;370(2):295-309.

62. Schoggins JW, Rice CM. Innate immune responses to hepatitis C virus. Curr Top Microbiol Immunol. 2013;369:219-242.

63. Ivanov AV, Bartosch B, Smirnova OA, Isaguliants MG, Kochetkov SN. HCV and oxidative stress in the liver. Viruses. 2013;5(2):439-469.

64. Gong G, Waris G, Tanveer R, Siddiqui A. Human hepatitis C virus NS5A protein alters intracellular calcium levels, induces oxidative stress, and activates STAT-3 and NF-kappa B. Proc Natl Acad Sci USA. 2001;98(17):9599-9604.

65. Bishé B, Syed G, Siddiqui A. Phosphoinositides in the hepatitis C virus life cycle. Viruses. 2012;4(10):2340-2358.

66. Zhang L, Hong Z, Lin W, et al. ARF1 and GBF1 generate a PI4Penriched environment supportive of hepatitis $\mathrm{C}$ virus replication. PLoS One. 2012;7(2):e32135.

67. Ploen D, Hafirassou ML, Himmelsbach K, et al. TIP47 plays a crucial role in the life cycle of hepatitis C virus. J Hepatol. 2013;58(6): 1081-1088.

68. Vogt DA, Camus G, Herker E, et al. Lipid droplet-binding protein TIP47 regulates hepatitis $\mathrm{C}$ Virus RNA replication through interaction with the viral NS5A protein. PLoS Pathog. 2013;9(4):e1003302.

69. Dahari H, Cotler SJ, Layden TJ, Perelson AS. Understanding triphasic $\mathrm{HCV}$ decline during treatment in the era of IL28B polymorphisms and direct acting antiviral agents via mathematical modeling. J Hepatol. 2013;58(4):840-842.

70. Guedj J, Dahari H, Rong L, et al. Modeling shows that the NS5A inhibitor daclatasvir has two modes of action and yields a shorter estimate of the hepatitis C virus half-life. Proc Natl Acad Sci USA. 2013;110(10): 3991-3996.

71. Macdonald A, Harris M. Hepatitis C virus NS5A: tales of a promiscuous protein. J Gen Virol. 2004;85(Pt 9):2485-2502.

72. Masaki T, Suzuki R, Murakami K, et al. Interaction of hepatitis C virus nonstructural protein $5 \mathrm{~A}$ with core protein is critical for the production of infectious virus particles. J Virol. 2008;82(16):7964-7976.

73. Ma Y, Anantpadma M, Timpe JM, et al. Hepatitis C virus NS2 protein serves as a scaffold for virus assembly by interacting with both structural and nonstructural proteins. J Virol. 2011;85(1):86-97.

74. Gouklani H, Beyer C, Drummer H, Gowans EJ, Netter HJ, Haqshenas G. Identification of specific regions in hepatitis $\mathrm{C}$ virus core, NS2 and NS5A that genetically interact with $\mathrm{p} 7$ and co-ordinate infectious virus production. J Viral Hepat. 2013;20(4):e66-e71.

75. Quezada EM, Kane CM. The stimulatory mechanism of hepatitis $\mathrm{C}$ virus NS5A protein on the NS5B catalyzed replication reaction in vitro. Open Biochem J. 2013;7:11-14.

76. Quezada EM, Kane CM. The hepatitis C virus NS5A stimulates NS5B during in vitro RNA synthesis in a template specific manner. Open Biochem J. 2009;3:39-48.

77. Foster TL, Belyaeva T, Stonehouse NJ, Pearson AR, Harris M. All three domains of the hepatitis $\mathrm{C}$ virus nonstructural NS5A protein contribute to RNA binding. J Virol. 2010;84(18):9267-9277.

78. Targett-Adams P, Graham EJ, Middleton J, et al. Small molecules targeting hepatitis $\mathrm{C}$ virus-encoded NS5A cause subcellular redistribution of their target: insights into compound modes of action. $J$ Virol. 2011;85(13):6353-6368.

79. Lee C, Ma H, Hang JQ, et al. The hepatitis C virus NS5A inhibitor (BMS-790052) alters the subcellular localization of the NS5A nonstructural viral protein. Virology. 2011;414(1):10-18.

80. Camus G, Herker E, Modi AA, et al. Diacylglycerol acyltransferase-1 localizes hepatitis $\mathrm{C}$ virus NS5A protein to lipid droplets and enhances NS5A interaction with the viral capsid core. J Biol Chem. 2013;288(14): 9915-9923.
81. Reiss S, Rebhan I, Backes P, et al. Recruitment and activation of a lipid kinase by hepatitis C virus NS5A is essential for integrity of the membranous replication compartment. Cell Host Microbe. 2011;9(1):32-45.

82. Carvalho FA, Carneiro FA, Martins IC, et al. Dengue virus capsid protein binding to hepatic lipid droplets (LD) is potassium ion dependent and is mediated by LD surface proteins. J Virol. 2012;86(4):2096-2108.

83. Samsa MM, Mondotte JA, Iglesias NG, et al. Dengue virus capsid protein usurps lipid droplets for viral particle formation. PLoS Pathog. 2009;5(10):e1000632.

84. Lemm JA, O’Boyle D 2nd, Liu M, et al. Identification of hepatitis C virus NS5A inhibitors. J Virol. 2010;84(1):482-491.

85. Lemm JA, Leet JE, O'Boyle DR, et al. Discovery of potent hepatitis C virus NS5A inhibitors with dimeric structures. Antimicrob Agents Chemother. 2011;55(8):3795-3802.

86. Gao M, Nettles RE, Belema M, et al. Chemical genetics strategy identifies an HCV NS5A inhibitor with a potent clinical effect. Nature. 2010;465(7294):96-100.

87. Conte I, Giuliano C, Ercolani C, et al. Synthesis and SAR of piperazinyl$\mathrm{N}$-phenylbenzamides as inhibitors of hepatitis $\mathrm{C}$ virus RNA replication in cell culture. Bioorg Med Chem Lett. 2009;19(6):1779-1783.

88. Barnes M, Dennison H, Matthews N, Spencer K, inventors; Arrow Therapeutics Ltd, assignee. Morpholinylanilinoquinazoline derivatives for use as antiviral agents. US patent US 20080311076A1.

89. Bianco A, Reghellin V, Donnici L, et al. Metabolism of phosphatidylinositol 4-kinase III $\alpha$-dependent PI4P Is subverted by HCV and is targeted by a 4-anilino quinazoline with antiviral activity. PLoS Pathog. 2012;8(3):e1002576.

90. Lim YS, Hwang SB. Hepatitis C virus NS5A protein interacts with phosphatidylinositol 4-kinase type IIIalpha and regulates viral propagation. J Biol Chem. 2011;286(13):11290-11298.

91. Amblard F, Zhang H, Zhou L, et al. Synthesis and evaluation of nondimeric HCV NS5A inhibitors. Bioorg Med Chem Lett. 2013;23(7): 2031-2034.

92. Zhang H, Zhou L, Amblard F, et al. Synthesis and evaluation of novel potent HCV NS5A inhibitors. Bioorg Med Chem Lett. 2012;22(14): 4864-4868.

93. Shi J, Zhou L, Amblard F, et al. Synthesis and biological evaluation of new potent and selective HCV NS5A inhibitors. Bioorg Med Chem Lett. 2012;22(10):3488-3491.

94. Chang W, Mosley RT, Bansal S, et al. Inhibition of hepatitis C virus NS5A by fluoro-olefin based $\gamma$-turn mimetics. Bioorg Med Chem Lett. 2012;22(8):2938-2942.

95. Aghemo A, Colombo M. Selection of resistant-associated variants to the NS5A inhibitor daclatasvir: revenge of the hepatitis $\mathrm{C}$ virus. Gastroenterology. 2013;145(1):247-249.

96. Fridell RA, Qiu D, Wang C, Valera L, Gao M. Resistance analysis of the hepatitis C virus NS5A inhibitor BMS-790052 in an in vitro replicon system. Antimicrob Agents Chemother. 2010;54(9):3641-3650.

97. Fridell RA, Wang C, Sun JH, et al. Genotypic and phenotypic analysis of variants resistant to hepatitis $\mathrm{C}$ virus nonstructural protein $5 \mathrm{~A}$ replication complex inhibitor BMS-790052 in humans: in vitro and in vivo correlations. Hepatology. 2011;54(6):1924-1935.

98. O'Boyle Ii DR, Sun JH, Nower PT, et al. Characterizations of HCV NS5A replication complex inhibitors. Virology. 2013;444(1-2):343-354.

99. Nettles RE, Gao M, Bifano M, et al. Multiple ascending dose study of BMS-790052, a nonstructural protein 5A replication complex inhibitor, in patients infected with hepatitis C virus genotype 1. Hepatology. 2011;54(6):1956-1965.

100. Pawlotsky JM. NS5A inhibitors in the treatment of hepatitis C. J Hepatol. 2013;59(2):375-382.

101. Lok AS, Gardiner DF, Lawitz E, et al. Preliminary study of two antiviral agents for hepatitis C genotype 1. N Engl J Med. 2012;366(3): 216-224.

102. Everson GT, Sims KD, Rodriguez-Torres M, et al. Interim analysis of an interferon (IFN)- and ribavirin (RBV))-free regimen of daclatasvir (DCV), asunaprevir (ASV), and BSM-791325 in treatment-naive, hepatitis C virus genotype 1-infected patients. J Hepatol. 2013;58 Suppl 1:S573. abstract. 
103. Wong KA, Worth A, Martin R, et al. Characterization of hepatitis C virus resistance from a multiple dose clinical trial of the novel NS5A inhibitor GS-5885. Antimicrob Agents Chemother. Epub July 22, 2013.

104. Lawitz EJ, Gruener D, Hill JM, et al. A phase 1, randomized, placebo-controlled, 3-day, dose-ranging study of GS-5885, an NS5A inhibitor, in patients with genotype 1 hepatitis C. $J$ Hepatol. 2012;57(1):24-31.

105. Gane E, Hyland R, Ding X, et al. ELECTRON: $100 \%$ suppression of viral load through 4 weeks' post-treatment for sofosbuvir ledipasvir (gs-5885) ribavirin for 12 weeks in treatment-naïve and -experienced hepatitis C virus GT 1 Patients. Presented at the 20th Conference on Retroviruses and Opportunistic Infections; March 3-6, 2013; Atlanta, GA.

106. Gilead Sciences. Gilead reports interim data from Phase 2 LONESTAR study [press release]. Foster City, CA: Gilead Sciences; 2013 [May 2]. Available from: http://investors.gilead.com/phoenix. zhtml?c=69964\&p=irol-newsArticle\&ID=1814329\&highlight\#stha sh.eUDZEi5S.dpuf2013. Accessed October 2, 2013.

107. Marcellin P, Manns MP, Janczewska E, et al. 12 week responseguided treatment with the NS5A inhibitor, GS-5885, the NS3 protease inhibitor, GS-9451, plus pegylated interferon/ribavirin in treatment naive genotype 1 hepatitis $\mathrm{C}$ infected patients. Abstract presented at the 48th Annual Meeting of the European Association for the Study of the Liver; April 24-28, 2013; Amsterdam, The Netherlands.

108. Everson GT, di Bisceglie AM, Vierling JM, et al. Combination of the NS5A inhibitor, GS-5885, the NS3 protease inhibitor, GS-9451, and pegylated interferon plus ribavirin in treatment experienced patients with genotype 1 hepatitis $C$ infection. Abstract presented at the 48th Annual Meeting of the European Association for the Study of the Liver; April 24-28, 2013; Amsterdam, The Netherlands.

109. Thompson A, Han S, Shiffman ML, et al. GS-5885 GS-9451 Peginterferon and ribavirin (PR) for six or twelve weeks achieves high SVR12 rates in treatment -naïve genotype a IL28B CC patients. Abstract presented at the 48th Annual Meeting of the European Association for the Study of the Liver; April 24-28, 2013; Amsterdam, The Netherlands.

110. Gilead Sciences. Gilead announces update on Phase 3 study of oral fixed-dose combination of sofosbuvir and ledipasvir for genotype 1 hepatitis C patients [press release]. Foster City, CA: Gilead Sciences; 2013 [March 26]. Available from: http://investors.gilead.com/phoenix. zhtml?c=69964\&p=irol-newsArticle \&ID=1800517\&highlight\#sthas h.9dxD7UZn.dpuf2013. Accessed October 2, 2013.

111. Kowdley KV, Lawitz E, Poordad F, et al. Phase $2 \mathrm{~b}$ trial of interferon-free therapy for hepatitis C virus genotype 1. $N$ Engl J Med. 2014;370:222-232.

112. Vince B, Hill JM, Lawitz EJ, et al. A randomized, double-blind, multiple-dose study of the pan-genotypic NS5A inhibitor samatasvir in patients infected with hepatitis $\mathrm{C}$ virus genotype $1,2,3$ or $4 . J$ Hepatol. Epub 2014 Jan 13.

113. Lahser F, Liu R, Bystol K, et al. A combination containing MK5172 (HCV NS3 protease inhibitor) and MK-8742 (HCV NS5A inhibitor) demonstrates high barrier to resistance in $\mathrm{HCV}$ replicon. Presented at the 63rd Annual Meeting of the American Association for the Study of Liver Diseases; November 9-13, 2012; Boston, MA.

114. Gane E, Foster GR, Clanciara J, et al. Antiviral activity, pharmacokinetics, and tolerability of AZD7295, a novel NS5A inhibitor, in a placebo-controlled multiple ascending dose study in HCV genotype 1 and 3 patients. Abstract presented at the 45th Annual Meeting of the European Association for the Study of the Liver; April 14-18, 2010; Vienna, Austria.

115. Spreen W, Wilfret D, Bechtel J, et al. GSK2336805 HCV NS5A inhibitor demonstrates potent antiviral activity in chronic hepatitis $\mathrm{C}(\mathrm{CHC})$ genotype 1 infection: Results from a first time in human (FTIH) single and repeat dose study. Presented at the 62nd Annual Meeting of the American Association for the Study of Liver Diseases; November 6-9, 2011; San Francisco, CA
116. Vertex Pharmaceuticals Incorporated. Vertex enters agreement with GlaxoSmithKline for Phase 2 all-oral study of VX-135 and GSK2336805 for the treatment of hepatitis C [press release]. Cambridge, MA: Vertex Pharmaceuticals Incorporated; 2012 [Nov 1]. Available from: http://investors.vrtx.com/releasedetail. cfm?ReleaseID=717777. 2013. Accessed November 20, 2013.

117. Lalezari J, Farrell G, Shah P, et al. PPI-668, a potent new pan-genotypic HCV NS5A inhibitor: Phase 1 efficacy and safety. Presented at the 63rd Annual Meeting of the American Association for the Study of Liver Diseases; November 9-13, 2012; Boston, MA.

118. German P, Pang P, Yang C, et al. Healthy volunteer first-in-human evaluation of GS-5816, a novel second generation broad-genotypic NS5A inhibitor with potential for once-daily dosing. Abstract presented at the 48th Annual Meeting of the European Association for the Study of the Liver; April 24-28, 2013; Amsterdam, The Netherlands.

119. Cheng G, Yu M, Peng B, et al. GS-5816, a second generation HCV NS5A inhibitor with potent antiviral activity, broad genotypic coverage and a high resistance barrier. Abstract presented at the 48th Annual Meeting of the European Association for the Study of the Liver; April 24-28, 2013; Amsterdam, The Netherlands.

120. Gilead Sciences. Phase 2 Study of SOF+GS-5816 in treatment naive subjects with chronic HCV. Available from: http://clinicaltrials.gov/ ct2/show/NCT01858766. NLM identifier: NCT01858766. Accessed October 2, 2013

121. Vince B, Lawitz E, Searle S, et al. Novel NS5A inhibitor ACH-2928 Phase I results in HCV GT-1 patients. Abstract presented at the 47th Annual Meeting of the European Association for the Study of the Liver; April 18-22, 2012; Barcelona, Spain.

122. Garcia-Rivera J, Chatterji U, Gallay P. Cyclophilin inhibitor alisporivir (ALV) combinations with direct acting antivirals reveal strong synergistic anti-HCV effects. Abstract presented at the 48th Annual Meeting of the European Association for the Study of the Liver; April 24-28, 2013; Amsterdam, the Netherlands.

123. Lalezari J, Agarwal K, Dusheiko G, et al. Dose-ranging trial of PPI-461, a potent new pan-genotypic HCV NS5A inhibitor, in patients with HCV genotype-1 infection. Abstract presented at the 62nd Annual Meeting of the American Association for the Study of Liver Diseases; November 5-9, 2011; San Francisco, CA.

124. Dumas E, Lawal A, Menon R, et al. Pharmacokinetics, safety and tolerability of the HCV NS5a inhibitor ABT-267 following single and multiple doses in healthy adult volunteers. Abstract presented at the 46th Annual Meeting of the European Association for the Study of the Liver; March 30-April 3, 2011; Berlin, Germany.

125. Hui J, Robarge L, Robison H, Kocinsky HS, Deshpande M. No clinically significant pharmacokinetic interaction between sovaprevir and ACH-3102 in healthy volunteers. Abstract presented at the 48th Annual Meeting of the European Association for the Study of the Liver; April 24-28, 2013; Amsterdam, The Netherlands.

126. Bristol-Myers Squibb. A phase 3 study in combination with BMS-790052 and BMS-650032 in Japanese hepatitis C virus (HCV) patients. Available from: http://clinicaltrials.gov/ct2/show/ NCT01497834. NLM identifier: NCT01497834. Accessed October 10, 2013.

127. Gilead Sciences. Safety and efficacy of sofosbuvir/GS-5885 fixed-dose combination \pm ribavirin for the treatment of $\mathrm{HCV}$ (ION-2). Available from: http://clinicaltrials.gov/ct2/show/NCT01768286. NLM identifier: NCT01768286. Accessed October 2, 2013.

128. Mayers D, Vince B, Hill J, et al. IDX719, HCV NS5A inhibitor, demonstrates pan-genotypic activity after three days of monotherapy in genotype 1, 2, 3 or $4 \mathrm{HCV}$-infected subjects. Abstract presented at the 63rd Annual Meeting of the American Association for the Study of Liver Diseases; November 9-13, 2012; Boston, MA.

129. Zhou XJ, Vince B, Hill J, et al. Pharmacokinetics and pharmacodynamics of IDX719, a pan-genotypic HCV NS5A inhibitor in genotype 1, 2, 3 or $4 \mathrm{HCV}$-infected subjects. Abstract presented at the Asian Pacific Association for the Study of the Liver; June 6-10, 2013; Singapore. 
130. Merck. Safety, Pharmacokinetics and pharmacodynamics of MK-8742 in hepatitis C infected males (MK-8742-8002 AM1). Available from: http://clinicaltrials.gov/ct2/show/NCT01532973. NLM identifier: NCT01532973. Accessed October 10, 2013.

131. Abbott Laboratories. Abbott presents promising Phase $2 \mathrm{~b}$ interferonfree hepatitis $C$ results at 2012 liver meeting ${ }^{\circledR}$ [press release]. Abbott Park, IL: Abbott Laboratories; 2012 [November 10]. Available from: http://www.abbott.com/news-media/press-releases/abbott-presentspromising-phase-2b-interferonfree-hepatitis-c-results-at-2012-livermeeting.htm. Accessed June 27, 2013.

132. clinical trialfacts.com [homepage on the Internet]. Effect of omeprazole and ritonavir on GSK2336805 pharmacokinetics in healthy adults. ClinicalTrialfacts.com; 2011 [updated October 1, 2013]. Available from: http://www.clinicaltrialfacts.com/hepatitis-c-chronic/effect-ofomeprazole-and-ritonavir-on-gs-115217/summary. Accessed October $13,2013$.
133. investorshub.advfn.com [homepage on the Internet]. Post 94863. Investors Hub; 2010. Available from: http://investorshub.advfn.com/ boards/read_msg.aspx?message_id=49610323. Accessed October 13, 2013.

134. bms.com [homepage on the Internet]. Pipeline asset update for daclatasvir (DCV; BMS-790052). Bristol-Myers Squibb; 2012 [cited July 15, 2013]. Available from: http://www.bms.com/research/ investigational/hepatitis/Pages/DCV-BMS-790052.aspx. Accessed October 13, 2013.

\section{Publish your work in this journal}

Infection and Drug Resistance is an international, peer-reviewed openaccess journal that focuses on the optimal treatment of infection (bacterial, fungal and viral) and the development and institution of preventive strategies to minimize the development and spread of resistance. The journal is specifically concerned with the epidemiology of antibiotic

\section{Dovepress}

resistance and the mechanisms of resistance development and diffusion in both hospitals and the community. The manuscript management system is completely online and includes a very quick and fair peerreview system, which is all easy to use. Visit http://www.dovepress.com/ testimonials.php to read real quotes from published authors.

Submit your manuscript here: http://www.dovepress.com/infection-and-drug-resistance-journal 